\title{
Preferences and attitudes towards açaí-based products among North American consumers
}

\author{
Ellen Menezes ${ }^{\mathrm{a}, \mathrm{b}, *}$, Rosires Deliza ${ }^{\mathrm{c}}$, Ho Lim Chan ${ }^{\mathrm{b}}$, Jean-Xavier Guinard ${ }^{\mathrm{b}}$

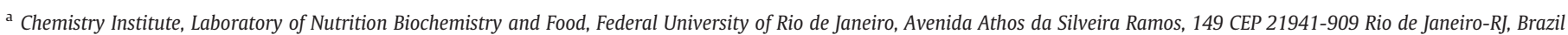 \\ b Department of Food Science and Technology, University of California, One Shields Ave., Davis 95616, USA \\ c Embrapa Labex Europe, INRA, UMR CSGA, 21065 Dijon, France
}

\section{A R T I C L E I N F O}

\section{Article history:}

Received 1 January 2011

Accepted 25 February 2011

\section{Keywords:}

Açaí

Euterpe oleracea, Mart.

American

Consumer

Liking

Purchase intent

\begin{abstract}
A B S T R A C T
Euterpe oleracea, Mart. is a palm tree widely distributed in South America and the juice which is prepared from its eatable pulp is popularly called "açaí" in Brazil. It has a high nutritional value consisting mainly of fat, fiber and vitamin and minerals, but is also rich in anthocyanins, phenolic compounds and demonstrates high antioxidant capacity. The aim of this study was to evaluate North American consumers' acceptance, intention to purchase and attitudes towards different açaí-based products available in the US. Acceptance and purchase intention tests were carried out with 155 consumers for seven different açaí-based products. Demographics and attitudes were also measured in an exit survey. A sorbet, a juice and a smoothie were the most liked products but purchase intentions were relatively low. Overall liking was driven by liking for flavor and aftertaste of the products. Consumers' segmentation based on acceptance revealed three groups, with a segment of açaí likers and another of dislikers. Most consumers had heard of açaí (83.9\%) and 55.5\% had tasted it before. Consumers knew açaí was healthy, nutritive, and rich in vitamins, minerals and antioxidants; however they did not know that açaí was oily, rich in fiber and that it may prevent degenerative diseases. Most participants showed low food neophobia (67.7\%) and $51 \%$ scored high in general health interest. A promising market for açaí-based products among American consumers maybe women and health conscious consumers.
\end{abstract}

(c) 2011 Elsevier Ltd. All rights reserved.

\section{Introduction}

Açaí (Euterpe oleracea, Mart.) is a palm tree distributed in northern South America with its greatest occurrence and economic importance in the flood plains of the Brazilian Amazonian State of Pará (Brondizio, Safar, \& Siqueira, 2002; Murrieta, Dufour, \& Siqueira, 1999). A wide variety of marketable products are produced from that palm, but the fruits, which are mainly harvested from July to December, are the most important edible product (Del Pozo-Insfran, Brenes, \& Talcott, 2004). Euterpe olaracea, Mart. fruit is round, dark purple, measures from 1.0 to $1.4 \mathrm{~cm}$ in diameter and has a single seed that constitutes approximately $80 \%$ of the total volume, covered by fibrous layers and a slight oily coating under a thin edible mesocarp (Rogez, 2000). Açaí is never eaten fresh. A juice is prepared from the eatable pulp of the fruit and it is popularly called "açaí" in Brazil. The final product is a thick beverage of creamy texture, oily appearance and characteristic flavor (Pacheco-Palencia, Hawken, \& Talcott, 2007).

Açaí is a highly nutritive food, rich in fat, fiber, vitamins and minerals (Lichtenthäler et al., 2005; Menezes, Torres, \& Sabaa Srur,

\footnotetext{
* Corresponding author at: Chemistry Institute, Laboratory of Nutrition Biochemistry and Food, Federal University of Rio de Janeiro, Avenida Athos da Silveira Ramos, 149 CEP 21941-909 Rio de Janeiro-RJ, Brazil. Tel./fax: +55 2124532213.

E-mail address: ellenmayra@hotmail.com (E. Menezes).
}

2008; Neida \& Elba, 2007; Schauss, Wu, Prior, Ou, Patel, et al., 2006). It also performs an important phytochemical composition, accounted for high anthocyanin and phenolics which has been associated with antioxidant proprieties and health-related benefits, giving it the status of a functional food or a superfood (Bobbio, Druzian, Abrão, Bobbio, \& Fadelli, 2000; Coïsson, Travaglia, Piana, Capasso, \& Arlorio, 2005; Del Pozo-Insfran et al., 2004; Gallori, Bilia, Bergonzi, Barbosa, \& Vincieri, 2004; Hassimotto, Genovese, \& Lajolo, 2005; Lichtenthäler et al., 2005; Pacheco-Palencia et al., 2007; Rogez, 2000; Schauss, Wu, Prior, Ou, Huang, et al., 2006; Schauss, Wu, Prior, Ou, Patel, et al., 2006). Mertens-Talcott et al. (2008) reported that the consumption of açaí juice or pulp by healthy volunteers caused a significant increase in their plasma antioxidant capacity, demonstrating how natural antioxidants contribute to health promotion, as also stated by Schauss, Wu, Prior, Ou, Huang, et al. (2006), Del Pozo-Insfran, Percival, and Talcott (2006), Rocha et al. (2007) and Souza, Silva, Silva, Oliveira, and Pedrosa (2010).

In the 90s, the commercialization of this tropical fruit went through an economic boom, not only on the Brazilian market, but also at the international level (USA, Japan and Europe) (Pompeu, Silva, \& Rogez, 2009). Açai has greatly gained in commercial export markets favored by international consumer trends towards health, wellness, novelty and exotic flavors (Pacheco-Palencia, Duncan, \& Talcott, 2009). Interest in açaí has grown in the US (California, Texas, Florida 
and New York) (Brondizio, 2008), making it the most important export market for the Brazilian açaí pulp (Sabbe, Verbeke, Deliza, Matta, \& van Damme, 2009a). Açaí is used as an ingredient, bringing innovation (Guerrero et al., 2009), and recombination of components (Moskowitz, Reisner, Itty, Katz, \& Krieger, 2006) allowing the development of functional foods such as yogurts (Almeida et al., 2008; Coïsson et al., 2005). Besides, according to chefs from the American Culinary Federation (ACF), açaí remains in the top superfruit choices (NRA, 2008), specially as a component of functional beverages.

Since consumers believe more and more that foods contribute directly to their health (Mollet \& Rowland, 2002), an increase in the functional food market has been observed (Barrios, Bayarri, Carbonell, Izquierdo, \& Costell, 2011). Nevertheless, the development of functional foods products can be very challenging and food manufacturers need to ensure that these new products and ideas meet consumer expectations (Tudoran, Olsen, \& Dopico, 2009; Urala \& Lähteenmäki, 2007). Therefore, açaí may have a potential usage in innovative fruit juice formulations when aiming at satisfying healthrelated consumer demands (Lähteenmäki, Lyly, \& Urala, 2007).

Few consumer studies have been developed with açaí and so far no scientific research has been carried out on açaí among North Americans. A study with Belgian individuals, who were not familiar with açaí, was developed by Sabbe et al. (2009a). They investigated the acceptance of a new açaí fruit juice ( $40 \%$ açaí) compared to juices with different concentrations of açaí (4 to 20\%) available in the European market. Results showed that the majority (69\%) of consumers preferred the more familiar and common flavor of juices with a low açaí content (4 and 5\%). In another study, Sabbe, Verbeke, Deliza, Matta, and Van Damme (2009b) investigated the effect of health claims and personal characteristics on consumer acceptance of açaí juices. Results showed that consumers' acceptance and intention to purchase of açaí juices with 4 and $40 \%$ of açaí was driven by their sensory pleasure, and less by claimed health benefits. From these two studies, some information was gathered about foreigners' acceptance of açaí-based products, especially European consumers. However, no information is available for North Americans who are the primary importers of açaí pulp from Brazil.

Therefore, the aim of the study was to evaluate North American consumers' acceptance, intention to purchase and attitudes towards different açaí-based products available in the US. Consumers' knowledge of açaí and its nutritional proprieties, their food neophobia, general interest in health, and perceptions of functional foods were also explored.

\section{Material and methods}

\subsection{Açaí-based products}

Seven açaí-based products commercially available in Northern California (USA) were evaluated in September 2009 within four categories: one energy drink (A), three juices (B1, B2 and B3), one sorbet (C) and two smoothies (D1 and D2) (Table 1). The criteria to select the samples were to have no other fruit flavor mixed with açaí according to the front of the package, and to consider as many product categories as possible, within the fruit derivate segment. Both smoothies were prepared following the directions described on the back of the package. However, as smoothie D2 - the most consumed açaí product in the Southeast Brazil - had only açaí as the ingredient, $20 \%$ of guaraná syrup Strong ${ }^{\circledR}$ was added to sweeten it before serving (because açaí is not consumed on its own). That syrup percentage was based on a previous study developed in Brazil (Menezes, Unpublished results). The other samples were ready-to-consume products.

Samples were evaluated in sensory booths under white light at the Robert Mondavi Institute for Wine and Food Science Sensory Building of University of California, Davis. $30 \mathrm{~mL}$ for drinks or $30 \mathrm{~g}$ for sorbet
Table 1

Açaí based-products used in the study showing its category, nutritional information, and ingredients' list.

\begin{tabular}{|c|c|c|c|}
\hline Product & Category & $\begin{array}{l}\text { Nutritional } \\
\text { information }\end{array}$ & Ingredients list \\
\hline A & $\begin{array}{l}\text { Energy } \\
\text { drink }\end{array}$ & $\begin{array}{l}\text { Protein }=0 \mathrm{~g} \\
\text { Total fat }=0 \mathrm{~g} \\
\text { Total } \\
\text { carbohydrate }=20 \mathrm{~g}\end{array}$ & $\begin{array}{l}\text { Sparkling filtered water, organic } \\
\text { evaporated cane juice, organic clarified } \\
\text { açaí juice, organic acerola juice, } \\
\text { organic natural flavors, citric acid, } \\
\text { organic guaraná extract, Guayaki } \\
\text { organic yerba mate extract, Steaz } \\
\text { organic green tea extract, fruit and } \\
\text { vegetable juice }\end{array}$ \\
\hline B1 & Juice & $\begin{array}{l}\text { Protein }=1 \mathrm{~g} \\
\text { Total fat }=3.5 \mathrm{~g} \\
\text { Total } \\
\text { carbohydrate }=31 \mathrm{~g}\end{array}$ & $\begin{array}{l}\text { Organic açaí puree, organic agave } \\
\text { syrup, organic lime juice, }<0.5 \% \text { of } \\
\text { organic natural flavors, organic soy } \\
\text { lecithin, citric acid }\end{array}$ \\
\hline B2 & Juice & $\begin{array}{l}\text { Protein }=0 \mathrm{~g} \\
\text { Total fat }=0 \mathrm{~g} \\
\text { Total } \\
\text { carbohydrate }=23 \mathrm{~g}\end{array}$ & $\begin{array}{l}\text { Açaí juice, organic agave nectar, } \\
\text { natural flavors, citric acid }\end{array}$ \\
\hline B3 & Juice & $\begin{array}{l}\text { Protein }=1 \mathrm{~g} \\
\text { Total fat }=1.5 \mathrm{~g} \\
\text { Total } \\
\text { carbohydrate }=29 \mathrm{~g}\end{array}$ & $\begin{array}{l}\text { Organic açaí pulp, organic evaporated } \\
\text { cane juice, organic guaraná natural, } \\
\text { citric acid, soy lecithin, natural flavors }\end{array}$ \\
\hline C & Sorbet & $\begin{array}{l}\text { Protein }=1 \mathrm{~g} \\
\text { Total fat }=4 \mathrm{~g} \\
\text { Total } \\
\text { carbohydrate }=25 \mathrm{~g}\end{array}$ & $\begin{array}{l}\text { Organic açaí puree, organic evaporated } \\
\text { cane juice, organic tapioca syrup, } \\
<0.5 \% \text { of organic guaraná extract, } \\
\text { organic locust bean gum, organic guar } \\
\text { gum, organic soy lecithin, citric acid }\end{array}$ \\
\hline D1 & Smoothie & $\begin{array}{l}\text { Protein }=1 \mathrm{~g} \\
\text { Total fat }=4.5 \mathrm{~g} \\
\text { Total } \\
\text { carbohydrate }=15 \mathrm{~g}\end{array}$ & $\begin{array}{l}\text { Organic açaí puree, organic evaporated } \\
\text { cane juice, }<0.5 \% \text { of organic guaraná } \\
\text { extract, soy lecithin, citric acid }\end{array}$ \\
\hline $\mathrm{D} 2^{\mathrm{a}}$ & Smoothie & $\begin{array}{l}\text { Protein }=2 \mathrm{~g} \\
\text { Total fat }=6 \mathrm{~g} \\
\text { Total } \\
\text { carbohydrate }=4 \mathrm{~g}\end{array}$ & Açaí \\
\hline
\end{tabular}

Sample D2 was served with guaraná syrup $20 \%$.

and smoothies were monadically served in clear; three-digit coded plastic cups at $7{ }^{\circ} \mathrm{C}$ and $0{ }^{\circ} \mathrm{C}$, respectively, following a balanced order of samples' presentation to prevent carry over or first over effects (MacFie, Bratchell, Greenhoff, \& Vallis, 1989).

\subsection{Participants}

Advertisements about the study were emailed and displayed around campus and in the city of Davis. A booth was set up at the local Farmer's Market. One hundred and fifty five consumers took part in the study. Participant recruitment criteria were residency in the US (living in the US for over 10 years or US citizens), and willingness to participate regardless of prior açaí consumption or not. Consumers were mainly characterized as female, mean age of 31 years old (17 to 84), students with the highest education degree as high school diploma and with a low annual family income.

The study had prior approval from the Office of Human Research Protection (OHRP) and the Institutional Review Board (IRB) of the University of California, Davis.

\subsection{Consumer test}

Acceptance and purchase intention tests were carried out, and all products were evaluated by all consumers. Subjects were asked their overall liking, followed by their liking for the appearance, color, odor, flavor, mouthfeel and aftertaste of the products using a 9-point hedonic scale ( 1 = "dislike extremely", 2 = "dislike very much", $3=$ "dislike moderately", 4 = "dislike slightly", 5 = "neither like nor dislike", $6=$ "like slightly", 7 = "like moderately", $8=$ "like very much" and $9=$ "like extremely"), as well as their intention to purchase using a 7-point scale 
anchored at ends and middle ( 1 = "definitively would not buy it", $4=$ "maybe/maybe not buy it" and $7=$ "definitely would buy it") (Meilgaard, Civille, \& Carr, 1999). After tasting the products, consumers were asked to complete a questionnaire which included general questions about fruit derivates and organic products consumption, life style and açaí consumption. Seventeen statements about açaí properties established in a previous study carried out with Brazilians (Menezes, Unpublished results) were also considered in the survey. They were translated into English and pre-tested with North American respondents to verify the translation before the experimental work (Table 6). Participants were asked to indicate their agreement with the statements using a 7-point scale anchored at the edges and middle $(1=$ totally disagree; $4=$ neither disagree; nor agree; $7=$ totally agree).

Participants' tendency to avoid novel foods was measured using the Food Neophobia Scale (FNS) (Pliner \& Hobden, 1992) and consumers' interest in healthy eating was investigated using the General Health Interest (GHI) sub-scale developed by Roininen, Lähteenmäki, and Tuorila (1999). Respondents scored in a 7-point scale ( $1=$ totally disagree; $4=$ neither disagree; nor agree; $7=$ totally agree) their agreement with the statements.

Thirteen more statements about functional foods were included in the questionnaire based on Urala and Lähteenmäki (2004). Previous to the scales, the following definition of functional foods was given to the consumers: "Functional foods are demonstrated to affect beneficially one or more target functions in the body, beyond adequate nutritional effects, in a way that is relevant to either improve the state of health and well-being, and/or reduce the risk of disease" (Diplock et al., 1999). A US $\$ 15$ gift card was given to consumers for their participation.

\subsection{Data analysis}

The acceptance and intention to purchase scores were analyzed using two-way analysis of variance (ANOVA) considering samples and consumers as source of variations. Fisher test with the confidence interval of $95 \%$ was used for pairwise comparisons. Pearson correlation ( $r$ ) was carried out to investigate the relationship between overall liking and the other variables aiming at identifying drivers of liking.

Hedonic data were also analyzed using frequency distribution to check whether consumers' responses had a normal distribution behavior. Each entry corresponded to the frequency of scores within the hedonic scale interval of variation (1-9) and, in this way; the frequency summarizes the distribution of values in the sample. The distribution was not normal, as expected for hedonic data, and reported by Bayarri, Carbonell, Barrios, and Costell (2011) on their yogurt study. Therefore, the preference data were also analyzed using the Internal Preference Mapping (IPM) which provides a summary of the main preference directions and the associated consumer segments, i.e. it takes into account individual differences in product perception of preference, yielding a graphic representation of acceptance differences among products in a multidimensional space (Greenhoff \& MacFie, 1994). The preference data was submitted to an internal analysis of the correlation matrix. Previous studies on internal preference have demonstrated the possibility of testing how well individual consumers are fitted by the preference model and whether differences between product preferences are significant (e.g. Jaeger, Andani, Wakeling, \& MacFie, 1998; Jaeger, Rossiter, Wismer, \& Harker, 2003; Monteleone, Frewer, Wakeling, \& Mela, 1998).

Cluster analysis is being used as a supplement together with the preference mapping to make the results easier to interpret. In the present study, Agglomerative Hierarchical Clustering (AHC) analysis with Ward's method using Euclidean distances was also applied to identify segments of consumers based on degree of similarity among their hedonic scores (Jacobsen \& Gunderson, 1986; Vigneau, Qannari, Punter, \& Knoops, 2001).

Internal consistency of questionnaire data (Food Neophobia and, General Health Interest Scales, Functional Food and Açaí Proprieties Statements) was explored by simple tabulation of means and Factor Analysis (Principal Component Analysis with Varimax rotation). Cronbach's $\alpha$ (alpha) is a coefficient of reliability commonly used as a measure of the internal consistency. For the Food Neophobia Scales Cronbach's coefficient alpha (Cronbach, 1951) was 0.81. For the General Health Interest Scales, it was 0.77, 0.72 for the Functional Food Statements and 0.68 for the Açaí Proprieties. For the FNS the total score was calculated by summing the individual scores for each scale, then classified as low food neophobia consumer ( sum $\leq 25$ ) and as high FN (sum $\geq 35$ ) (Flight, Leppard, \& Cox, 2003) (theoretical possible range is 10-70) (Pliner \& Hobden, 1992). Average scores and standard deviations for each statement were calculated. For the GHI statements, consumer with mean value $\leq 3.9$ was considered as having low general interest for health, and $>5.1$ high interest (Roininen et al., 1999).

Chi-square test was used to check for differences among preference clusters regarding all questionnaire data, except from açaí proprieties and functional food statements. Individual contingency tables were prepared with variables (in lines) and clusters (in columns) before running the analysis. All statistical analyses were carried out using XLSTAT version 2007 and $\mathrm{p} \leq 0.05$ was established as a criterion of significance.

\section{Results and discussion}

\subsection{Açaí-based products acceptance and purchase intent}

Analysis of variance showed a significant effect $(\mathrm{p}<0.05)$ of samples on consumer product evaluation. Table 2 presents the average scores for overall liking, and also the appearance, odor, flavor, mouthfeel and aftertaste liking, as well as the intention to purchase for all evaluated products.

Product $C$ (sorbet) had the highest scores for overall liking (6.1), flavor (6.4) and aftertaste $(5.9)(\mathrm{p}<0.05)$ indicating consumer preferences to this type of product. Sorbets are most commonly commercialized as a non-dairy, fruit juice "Italian ice" product, also referred to as frozen desserts with sensory characteristics that may have been attracted consumers, suggesting that acceptance could be more associated with the product category. Since açaí is considered a functional food, and taking

Table 2

Consumer evaluation mean scores of açaí-based products $(n=155)$.

\begin{tabular}{|c|c|c|c|c|c|c|c|c|}
\hline Product & Overall liking§ & Appearance ${ }^{\S}$ & Color ${ }^{\S}$ & Odor $^{\S}$ & Flavor $^{\S}$ & Mouthfeel $^{\S}$ & Aftertaste ${ }^{\S}$ & Purchase intention $^{\S \S}$ \\
\hline$A$ & $4.5^{\mathrm{de}}$ & $7.1^{\mathrm{a}}$ & $7.2^{\mathrm{a}}$ & $5.2^{\mathrm{b}}$ & $4.1^{d}$ & $5.4^{\mathrm{c}}$ & $4.3^{\mathrm{cd}}$ & $2.7^{d}$ \\
\hline B1 & $5.6^{\mathrm{b}}$ & $5.2^{\mathrm{d}}$ & $5.3^{d}$ & $5.5^{\mathrm{ab}}$ & $5.7^{\mathrm{b}}$ & $5.8^{\mathrm{ab}}$ & $5.3^{\mathrm{b}}$ & $3.8^{\mathrm{b}}$ \\
\hline B2 & $4.7^{\text {de }}$ & $7.0^{\mathrm{ab}}$ & $7.1^{\mathrm{a}}$ & $5.3^{\mathrm{b}}$ & $4.6^{\mathrm{cd}}$ & $6.0^{\mathrm{a}}$ & $4.5^{\mathrm{cd}}$ & $3.2^{\mathrm{c}}$ \\
\hline B3 & $4.9^{\mathrm{cd}}$ & $5.6^{\mathrm{c}}$ & $5.8^{\mathrm{c}}$ & $5.5^{\mathrm{ab}}$ & $4.9^{c}$ & $5.5^{\mathrm{bc}}$ & $4.7^{c}$ & $3.3^{c}$ \\
\hline C & $6.1^{\mathrm{a}}$ & $6.7^{\mathrm{b}}$ & $6.4^{\mathrm{b}}$ & $5.6^{\mathrm{a}}$ & $6.4^{\mathrm{a}}$ & $6.0^{\mathrm{a}}$ & $5.9^{\mathrm{a}}$ & $4.5^{\mathrm{a}}$ \\
\hline D1 & $5.4^{\mathrm{bc}}$ & $5.7^{c}$ & $6.2^{\mathrm{bc}}$ & $5.4^{\mathrm{ab}}$ & $5.7^{\mathrm{b}}$ & $5.8^{\mathrm{ab}}$ & $5.3^{\mathrm{b}}$ & $3.9^{\mathrm{b}}$ \\
\hline D2 & $4.3^{\mathrm{e}}$ & $4.7^{\mathrm{e}}$ & $5.4^{\mathrm{d}}$ & $5.4^{\mathrm{ab}}$ & $4.4^{\mathrm{cd}}$ & $4.4^{\mathrm{d}}$ & $4.2^{\mathrm{d}}$ & $2.7^{d}$ \\
\hline
\end{tabular}

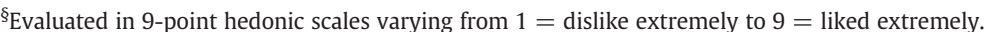

${ }^{\S}$ Evaluated in 7-point scale, varying form $1=$ definitely wouldn't buy to $7=$ definitely would buy.

Within columns, means that share a common letter are not significantly different $(p \leq 0.05)$.

A: energy drink; B: juice; C: sorbet; D: smoothie. 
into account the mentioned sorbet preference, this result corroborates to previous studies which have reported that consumers did not see functional products as a homogenous food category. The attractiveness of functional foods is influenced by the carrier, and one with a healthier image is more attractive than those lacking of such an image (Ares \& Gámbaro, 2007; Siegrist, Stampfli, \& Kastenholz, 2008; Urala \& Lähteenmäki, 2004; van Kleef, van Trijp, \& Luning, 2005). In line with this, product A (energy drink) perhaps might not have transmitted a good health image of a functional açaí product.

Besides the product category, the açaí content could also indicate preferences. Sabbe et al. (2009a) evaluated the consumer liking of fruit juices with different açaí concentrations in Belgium and noticed that flavor and overall liking decreased with the increasing of açaí concentrations. Although there was no information about the açaí concentration on labels of the açaí-based products; we did not observe similar results. Considering that the amount of any ingredient in a commercial product can be estimated by looking at its position in the ingredient list, the açaí content of samples A and D2 would represent a low and high concentration of açai in the products, respectively. No statistical difference was observed between these samples and both did not have a good performance in terms of acceptance.

Açaí original taste may be associated with its polyphenolic compounds which in general cause bitterness and astringency, as seen for several types of fruits (Lesschaeve \& Noble, 2005). Those descriptors can also contribute to decrease on consumer acceptability and willingness to purchase the product (Tuorila \& Cardello, 2002; Verbeke, 2006). In that respect, Ares, Barreiro, Deliza, and Gámbaro (2009) considered sweetness as an alternative to suppress bitterness, astringency and characteristic flavor of polyphenolic-rich antioxidant extracts in functional food. This result allows us to suggest that the sugar content of açaí-based products could also have influenced products preferences.

Juice B1 and smoothie D1 had the second highest average scores for overall liking and liking of flavor, 5.6 and 5.4, respectively (Table 2). It is worth saying that those products were all from the same producer. Results from recent research on açaí juices have shown different mean values. Vidigal, Minin, Carvalho, Milagres, \& Gonçalves (in press) evaluated the influence of information regarding health benefits on the acceptance of tropical fruit juices including açaí (35\% (w/w) pulp and $10 \%(\mathrm{w} / \mathrm{w})$ sugar) by 106 Brazilian consumers. Blind results revealed a mean score of 4.9 similar to juice B3, but below B1. On the other hand, Sabbe et al. (2009a, 2009b) reported lower score (3.2) for açaí juice with $40 \%$ of fruit among Belgium consumers.

In the present study, both products A (energy drink) and B2 (juice) had the highest acceptance mean for the appearance and color, despite consumers did not like them on overall. This might be because the energy drink (A) had an attractive light transparent red-pink color and juice (B2) a clarified purple-wine color, whereas other açaí products had a fade purple or purple-brownish color. There was a significant correlation between hedonic ratings of appearance and color $(r=0.953)$ (Table 3). Sabbe et al. (2009a) reported a negative effect of the dark-purplebrownish color on overall liking as the açaí concentration increased. Belgian consumers did not like that color and the more concentrated juices either.
All samples had very similar odor liking means (Table 2) which significantly correlated with flavor liking $(r=0.774)$ (Table 3$)$. According to Sabbe et al. (2009a), aroma and flavor seemed to be important explanatory factors for the juices' overall liking as most of their respondents mentioned a sweet pleasant odor for the juices with low açaí content, and a strong unpleasant odor for the juices with the highest açaí concentrations.

Smoothie D2 had the lowest mean scores for overall liking (4.3), liking of appearance (4.7), mouthfeel (4.4) and aftertaste (4.2) (Table 2). These results may indicate that North Americans did not like the way Southeastern Brazilians consume açaí. However, similar results were found in a study carried out with 125 Brazilians in March 2009 which evaluated consumers' liking of seven different smoothies made of açaí and $20 \%$ of guaraná syrup (Strong®). The smoothie D2 was among the evaluated samples, and the average overall liking score was 4.6 (Menezes, Unpublished results).

Consumers' intention to purchase for açaí-based products was in general low (Table 2). Sample C (sorbet) had a mean rating of 4.5, which was significantly higher than others, and it was followed by smoothie D1 (3.9) and juice B1 (3.8). No difference was observed between juices B2 and B3, average scores 3.2 and 3.3, respectively.

Table 3 shows that overall liking was strongly correlated to aftertaste $(r=0.995)$, purchase intention $(r=0.982)$ and flavor $(r=0.977)$, supporting literature findings that flavor and taste are very important for product acceptance (Luckow \& Delahunty, 2004; Lyly, Roininen, Honkapää, Poutanen, \& Lähteenmäki, 2007; Teh, Dougherty, \& Camire, 2007; Tuorila \& Cardello, 2002). However, other influences, such as cultural, physical and social environment might also contribute to one's behavior (Rozin, 1990). Significant correlations were also observed between appearance and color $(\mathrm{r}=0.953)$, flavor and aftertaste $(r=0.984)$ and, odor $(r=0.774)$ and purchase intent $(r=0.985)$.

The analysis of variance and mean tests have taken into account average scores, and failed to consider individual differences. In this case, it is assumed that the criterion of consumer acceptability is homogeneous (MacFie, 2007), but it is known that data arising from hedonic scales frequently break the assumption of normality and homocedasticity (O'Mahony, 1982), as can be seen in Fig. 1 which shows the distribution of frequencies for the overall liking scores ( 1 to 9 ) given by all 155 consumers for each investigated sample, and illustrates the characteristics of the data distributions. One can see that flat distributions with two modes; hence samples did not represent a normal distribution, suggesting that there were different likings for the same product. A mode appeared at the lower scale values (1 to 4) corresponding to a sample rejection and a second one in the area of acceptation at higher scale values (6 to 9), allowing one to detect likers and dislikers for the different categories of products. Similar results were reported by Carbonell, Bayarri, Navarro, Carbonell, \& Izquierdo (2009) and Bayarri et al. (2011) on acceptance data distribution for mandarin juices and fermented-milk products, respectively. Internal preference mapping was used to sort this problem out (Bayarri et al., 2011; Greenhoff \& MacFie, 1994; Guinard, Uotani, \& Schlich, 2001).

Internal preference mapping of the correlation matrix resulted in a two-factor solution accounting for $53.9 \%$ of the variation in the hedonic

Table 3

Pearson correlation coefficient ( $\mathrm{r}$ ) among variables.

\begin{tabular}{|c|c|c|c|c|c|c|c|c|}
\hline Variables & Overall & Appearance & Color & Odor & Flavor & Mouthfeel & After taste & Purchase intention \\
\hline Overall & 1 & 0.048 & -0.195 & 0.743 & 0.977 & 0.705 & 0.995 & 0.982 \\
\hline Appearance & & 1 & 0.953 & -0.293 & -0.110 & 0.557 & 0.022 & 0.044 \\
\hline Color & & & 1 & -0.525 & -0.323 & 0.384 & -0.209 & -0.170 \\
\hline Odor & & & & 1 & 0.774 & 0.224 & 0.736 & 0.736 \\
\hline Flavor & & & & & 1 & 0.583 & 0.984 & 0.985 \\
\hline Mouthfeel & & & & & & 1 & 0.655 & 0.687 \\
\hline Aftertaste & & & & & & & 1 & 0.982 \\
\hline Purchase intention & & & & & & & & 1 \\
\hline
\end{tabular}

Values in bold are different from 0 with a significance level alpha $=0.05$. 


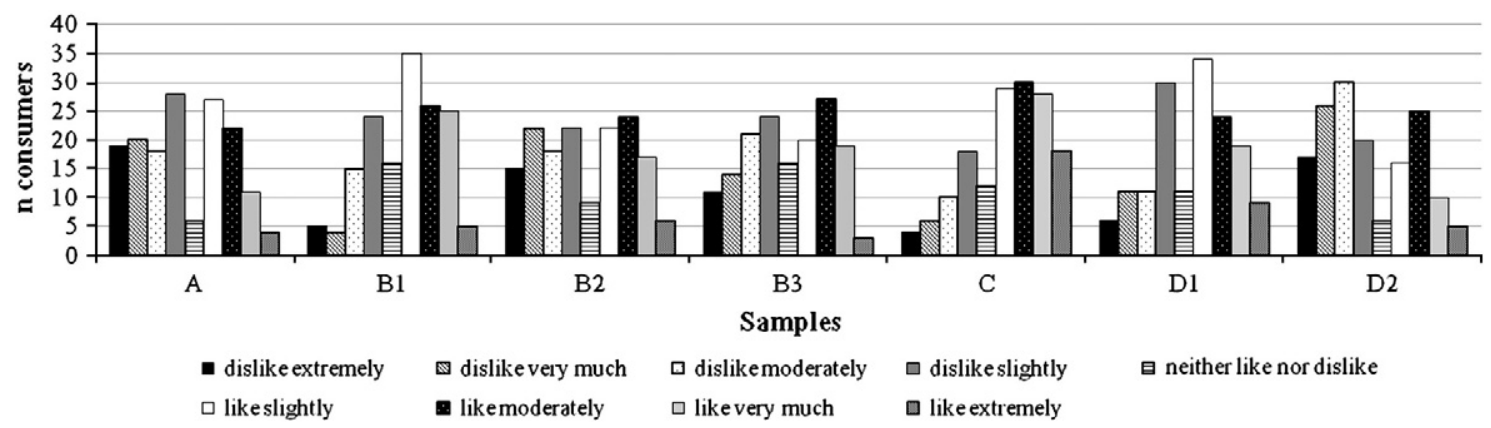

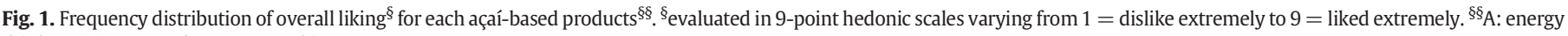
drink; B: juice; C: sorbet; D: smoothie.

data, of which $30.1 \%$ was accounted for by the first preference dimension, and $23.8 \%$ by the second (Fig. 2 ).

The first dimension separated samples in four groups, as follows: sample C (sorbet) from sample A (energy drink), and to a lesser extent B1

a

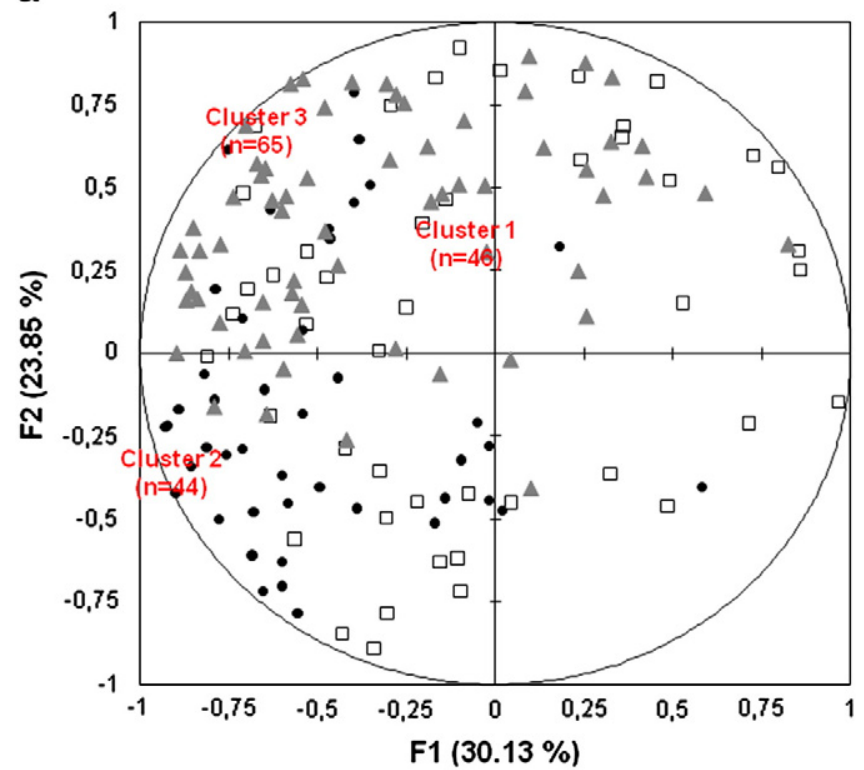

b

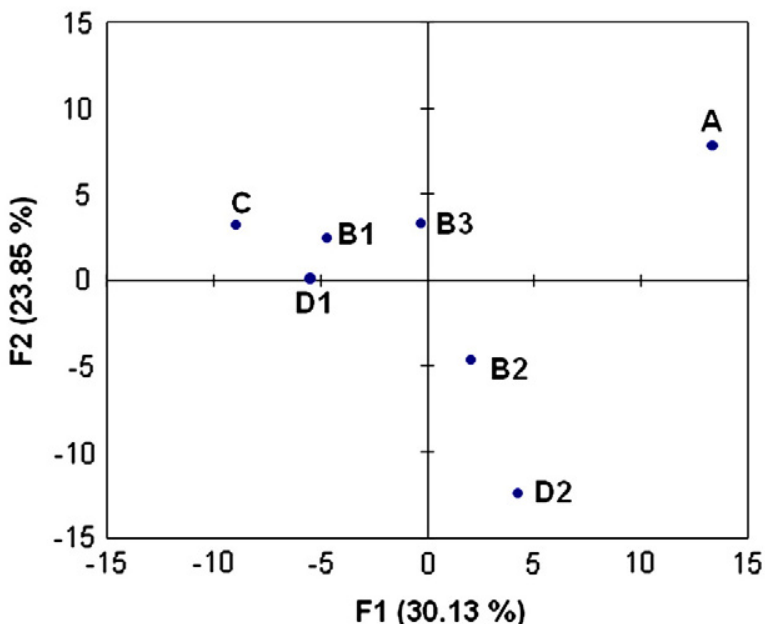

Fig. 2. Internal Preference Mapping of consumer acceptance for açaí based products $(n=155)$. (a) Plot of the two first preference dimension scores with consumer's position considering cluster $1(\square)$, cluster $2(\bullet)$ and cluster $3(\boldsymbol{\Delta})$; (b) Plot of the two first preference dimension loadings with product position.A: energy drink; B: juice; C: sorbet; D: smoothie. (juice) and D1 (smoothie), and B2, B3 and D2. On the second dimension, D2 (smoothie), A (energy drink) and to a lesser extent B2 were separated from the remaining samples, with the energy drink A located further apart. Consumers had different acceptance of the products and the two dimensions were good enough to discriminate samples. The majority of consumers were located in the left side of Fig. 2a revealing that samples $C$ (sorbet), B1 (juice) and D1 (smoothie) were the most liked products by participants (Fig. 2b). Those samples were from the same brand, suggesting that such higher acceptance might be related to the company's formulations. Besides, this brand is from one of the main companies that sell açaí-products in the US and it is widely distributed in local markets. As a consequence, those products might have been less unfamiliar to consumers, and such familiarity might have contributed to liking. On the other hand, samples B2 and D2 were the least liked.

The segments of consumers with similar liking can also be seen in Fig. 2a. The strategy of combining preference mapping with cluster analysis is useful to the results' interpretation (MacFie, 2007). Three segments of consumers were identified and the average scores are presented in Table 4.

Clusters differed in relation to the açaí-based product liking, except from the energy drink. Cluster 1 had 46 consumers $(29.7 \%$ of participants) and were the dislikers of açaí-based products, because the highest mean score was 4.5 , for juice B1, which was not statistically different from samples C, A and D2 means. Cluster 2 ( $n=44,28.4 \%$ of consumers) liked the majority of the açaí-based products, especially smoothie D1 that reached a mean score of 7.4 with no statistical difference from products $C$ and B2. However, they did not like the energy drink (sample A, mean 4.5). The energy drink in cluster 2 had an appreciation similar to the most liked product (B1) in cluster 1. Cluster 2 has given the highest hedonic scores across all samples and also expressed the highest purchase intent for the products.

Table 4

Means of overall liking§ and purchase intent ${ }^{\S \S}$ of the açaí based products.

\begin{tabular}{|c|c|c|c|c|c|c|}
\hline \multirow[b]{2}{*}{ Product } & \multicolumn{3}{|c|}{ Overall liking } & \multicolumn{3}{|c|}{ Purchase intent } \\
\hline & $\begin{array}{l}\text { Cluster } 1 \\
(n=46)\end{array}$ & $\begin{array}{l}\text { Cluster } 2 \\
(\mathrm{n}=44)\end{array}$ & $\begin{array}{l}\text { Cluster } 3 \\
(n=65)\end{array}$ & $\begin{array}{l}\text { Cluster } 1 \\
(\mathrm{n}=46)\end{array}$ & $\begin{array}{l}\text { Cluster } 2 \\
(\mathrm{n}=44)\end{array}$ & $\begin{array}{l}\text { Cluster } 3 \\
(\mathrm{n}=65)\end{array}$ \\
\hline A & $4.1^{\mathrm{Aab}}$ & $4.5^{\mathrm{Ad}}$ & $4.7^{\mathrm{Ac}}$ & $2.3^{\text {Aabc }}$ & $2.7^{\mathrm{Ac}}$ & $2.8^{\mathrm{Ac}}$ \\
\hline B1 & $4.5^{\mathrm{Ca}}$ & $6.6^{\mathrm{Abc}}$ & $5.7^{\mathrm{Bb}}$ & $2.7^{\mathrm{Cab}}$ & $4.6^{\mathrm{Ab}}$ & $4.0^{\mathrm{Bb}}$ \\
\hline B2 & $3.0^{\mathrm{Cd}}$ & $6.7^{\text {Aabc }}$ & $4.6^{\mathrm{Bc}}$ & $2.0^{\mathrm{Cc}}$ & $4.5^{\mathrm{Ab}}$ & $3.2^{\mathrm{Bc}}$ \\
\hline B3 & $3.6^{\mathrm{Cbcd}}$ & $6.5^{\mathrm{Ac}}$ & $4.8^{\mathrm{Bc}}$ & $2.2^{\mathrm{Cbc}}$ & $4.6^{\mathrm{Ab}}$ & $3.1^{\mathrm{Bc}}$ \\
\hline C & $4.3^{\mathrm{Cab}}$ & $7.3^{\mathrm{Aab}}$ & $6.6^{\mathrm{Ba}}$ & $3.0^{\mathrm{Ba}}$ & $5.5^{\mathrm{Aa}}$ & $5.0^{\mathrm{Aa}}$ \\
\hline D1 & $3.2^{\mathrm{ccd}}$ & $7.4^{\mathrm{Aa}}$ & $5.7^{\mathrm{Bb}}$ & $2.2^{\mathrm{Cbc}}$ & $5.5^{\mathrm{Aa}}$ & $4.0^{\mathrm{Bb}}$ \\
\hline D2 & $3.9^{\mathrm{Bab}}$ & $6.5^{\mathrm{Ac}}$ & $3.1^{\mathrm{Cd}}$ & $2.6^{\mathrm{Babc}}$ & $4.2^{\mathrm{Ab}}$ & $1.8^{\mathrm{Cd}}$ \\
\hline
\end{tabular}

Means in the same column followed by different low case letters imply a significant difference $(\mathrm{p} \leq 0.05)$ according to LSD test between samples.

Means in the same row followed by different capital letters imply a significant difference $(p \leq 0.05)$ according to LSD test between clusters ${ }^{\S}$ evaluated in 9-point hedonic scales varying from $1=$ dislike extremely to $9=$ liked extremely.

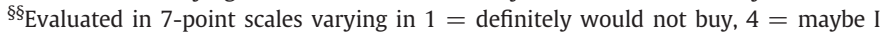
would buy, maybe not and 7 = definitely would buy.

A: energy drink; B: juice; C: sorbet; D: smoothie. 
Cluster 3 comprised $41.9 \%(n=65)$ of the consumers and preferred samples C, followed by B1 and D1, all from the same brand. This segment gave a higher average score (6.6) to the açaí sorbet (sample C). From the achieved results we can suggest consumers from cluster 2 as the potential market segment for açaí-based products.

Purchase intent and acceptance had similar pattern results. Hence, cluster 1 demonstrated lower means than cluster 3 and 2, suggesting that they seemed to be less willing to purchase the açaí-based products (Table 4). This latter, was the group with the highest means for purchase intent as observed for the sorbet (sample C) (5.5) and smoothie D1 (5.5).

\subsection{Consumer attitudes towards açaí}

Demographic variables such as age, level of education, income, ethnicity, and regional background also contribute to food and beverage choices (Tepper, Choi, \& Nayaga, 1997) and may strongly affect the acceptability or intention to use functional foods (Cox, Koster, \& Russell, 2004; Jong, Ocké, Branderhorst, \& Friele, 2003; Urala \& Lähteenmäki, 2004, 2007; Verbeke, 2005). Consumers' overall demographic information and the segmentation based on their preferences are shown in Table 5.

Table 5

Consumers' demographic characteristics (percentages).

\begin{tabular}{|c|c|c|c|c|c|}
\hline \multirow[t]{2}{*}{ Characteristics (\%) } & \multirow[b]{2}{*}{$\begin{array}{l}\mathrm{p} \text { level } \\
\text { values }\end{array}$} & \multirow{2}{*}{$\begin{array}{l}\text { Total } \\
\overline{n=155}\end{array}$} & \multirow{2}{*}{$\begin{array}{l}\text { Cluster } \\
\frac{1}{n=46}\end{array}$} & \multirow{2}{*}{$\begin{array}{l}\text { Cluster } \\
\frac{2}{n=44}\end{array}$} & \multirow{2}{*}{$\begin{array}{l}\text { Cluster } \\
\frac{3}{n=65}\end{array}$} \\
\hline & & & & & \\
\hline \multicolumn{6}{|l|}{ Gender } \\
\hline Male & 0.036 & 41.3 & 39.1 & 56.8 & 32.3 \\
\hline Female & & 58.7 & 60.9 & 43.2 & 67.7 \\
\hline \multicolumn{6}{|l|}{ Age(years) } \\
\hline $17-20$ & 0.056 & 27.1 & 30.4 & 15.9 & 32.3 \\
\hline $21-30$ & & 39.4 & 32.6 & 34.1 & 47.7 \\
\hline $31-40$ & & 9.7 & 8.7 & 13.6 & 7.7 \\
\hline $41-50$ & & 6.5 & 8.7 & 4.5 & 6.2 \\
\hline $51-60$ & & 10.3 & 8.7 & 20.5 & 4.6 \\
\hline$>60$ & & 7.1 & 10.9 & 11.4 & 1.5 \\
\hline \multicolumn{6}{|l|}{ Education level } \\
\hline High school diploma /GED & 0.461 & 49.0 & 47.8 & 38.6 & 56.9 \\
\hline Bachelor's degree & & 27.1 & 32.6 & 27.3 & 23.1 \\
\hline Master's degree & & 12.3 & 10.9 & 18.2 & 9.2 \\
\hline PhD's degree & & 6.5 & 2.2 & 11.4 & 6.2 \\
\hline Professional & & 5.2 & 6.5 & 4.5 & 4.6 \\
\hline \multicolumn{6}{|l|}{ Occupation } \\
\hline $\begin{array}{l}\text { Construction, extraction, } \\
\text { maintenance and repair }\end{array}$ & 0.078 & 0.0 & 0.0 & 0.0 & 0.0 \\
\hline Farming, fishing, and forestry & & 0.0 & 0.0 & 0.0 & 0.0 \\
\hline $\begin{array}{l}\text { Management, professional, and } \\
\text { related occupations }\end{array}$ & & 11.6 & 10.9 & 15.9 & 9.2 \\
\hline $\begin{array}{l}\text { Production, transportation, and } \\
\text { material moving }\end{array}$ & & 0.0 & 0.0 & 0.0 & 0.0 \\
\hline Retired & & 7.1 & 10.9 & 9.1 & 3.1 \\
\hline Sales and office & & 3.9 & 2.2 & 4.5 & 4.6 \\
\hline Service-related & & 2.6 & 2.2 & 6.8 & 0.0 \\
\hline Student & & 63.9 & 58.7 & 47.7 & 78.5 \\
\hline Unemployed & & 2.6 & 2.2 & 2.3 & 3.1 \\
\hline Other & & 8.4 & 13.0 & 13.6 & 1.5 \\
\hline \multicolumn{6}{|l|}{ Family income } \\
\hline$<$ US\$50,000 & 0.659 & 45.8 & 41.3 & 45.5 & 49.2 \\
\hline US $\$ 50,000-\$ 100,000$ & & 22.6 & 26.1 & 27.3 & 16.9 \\
\hline$>$ US $\$ 100,000$ & & 16.1 & 13.0 & 18.2 & 16.9 \\
\hline $\begin{array}{l}\text { Do not remember/prefer not } \\
\text { to report }\end{array}$ & & 15.5 & 19.6 & 9.1 & 16.9 \\
\hline \multicolumn{6}{|l|}{ Ethnicity } \\
\hline African & 0.480 & 0.0 & 0.0 & 0.0 & 0.0 \\
\hline Asian & & 32.9 & 37.0 & 20.5 & 38.5 \\
\hline Caucasian (non-Hispanic) & & 52.9 & 50.0 & 61.4 & 49.2 \\
\hline Hispanic/Latino & & 5.8 & 6.5 & 9.1 & 3.1 \\
\hline Native American & & 0.0 & 0.0 & 0.0 & 0.0 \\
\hline Pacific islander & & 1.9 & 2.2 & 0.0 & 3.1 \\
\hline Mixed & & 6.5 & 4.3 & 9.1 & 6.2 \\
\hline
\end{tabular}

The population was composed mainly of women (58.7\%). According to Bech-Larsen and Scholderer (2007), they do most of the shopping for their households, are also more health conscious (Ares, Giménez, \& Gámbaro, 2008; Jong et al., 2003), and more keen on natural food (Bäckström, Pirttilä-Backman, \& Tuorila, 2004). When considering the influence of gender on the importance of health factors, Vidigal et al. (in press) found a greater concern of women to consume healthy foods, and $83 \%$ of respondents reported the health benefits as factor that influences the consumption of fruit juices. That might as well be extended to other fruit derivate products.

Chi-square tests confirmed the relation between segments and gender $(p=0.036)$ and, segments and age $(p=0.056)$. Cluster 2 was composed mainly by males, and cluster 3 by young adults. Young adults (under 30 years) were majority (66.5\%) probably due to the study's location. Henriques, King, and Meiselman (2009) also suggested that younger consumers are more motivated to try new products and that might have stimulated this population to take part in the study. Cluster 2 , the group of açaí likers, had high percentage of people older than 51 years (31.9\%). Sabbe et al. (2009b) stated that functional products get indeed more of the elderly's attention than other age groups since they are more worried about healthiness and are more likely to improve or maintain their health status with consumption of that kind of foods. Previous studies have observed that older consumers are more likely to be(come) users of foods with additional health benefits (Bower, Saadat, \& Whitten, 2003; Lyly et al., 2007). Also, Verbeke (2006) observed that elderly were more ready to compromise on the taste of functional foods than men and younger consumers.

Consumers were all US residents and $87.7 \%$ were born in the US. They were born in different countries such as China who amounted to 4.5\%, Philippines, India, Iran, and others. Participants were mainly Caucasians (non-Hispanic) (52.9\%) and Asians (32.9\%). Individuals' education level was in accordance to their age, i.e. there were mostly high school degrees (49\%), despite the fact that there were also some consumers (27.1\%) with Bachelor's degrees.

Most of the consumers were students (63.9\%) followed by $11.6 \%$ professionals and related occupations. The main annual family income was lower than US\$50,000.00 (45.8\%) and between US\$50,000.00 and US\$100,000.00 (22.6\%). According to Bäckström et al. (2004), it is plausible that socio-economic status influences opportunity for exposure; for example, higher disposable income to eat outside home, and greater educational status providing better knowledge of cultural cuisines. Steptoe, Pollard, and Wardle (1995) reported that individuals with low income preferred familiar foods, but in our study no association was observed between education level and liking.

Regarding consumer responses to general questions on fruit based products, results showed that smoothies and homemade juices were liked best (96.8\%), and fruit pulp least (70.3\%). However, when asked which fruit based products consumers usually drank or ate, commercial juices (79.3\%) and smoothies (75.5\%) came first, which probably corresponded to the product categories they were more familiar with and, fruit purées last (21.9\%). Availability and familiarity appear to play also an important role on consumer attitudes and preferences. In Sveinsdóttir et al. (2009), clear differences in liking of fish products were observed in different countries appearing to be related to availability and familiarity of the products, and that may also be the case for açaí in the US. As mentioned before, the most liked products for all clusters were the smoothies and homemade juices, but when consumers were asked about their usual consumption, clusters 1 and 2 usually consumed commercial juices, 76.1 and $84.1 \%$, respectively, and cluster 3 consumed more often fruit smoothies (86.2\%) (chi-square test, $\mathrm{p}=0.018$ ). But, this last subgroup did not seem to have liked at all one of the açaí smoothies (sample D2) since the overall liking and flavor mean scores were 3.1 and 3.3, respectively, but they did like sample D1 (5.7 and 6.0) (Table 4, flavor data not shown).

In general, the fruit based products frequency of consumption revealed that participants hardly ever, or never had homemade juices, 


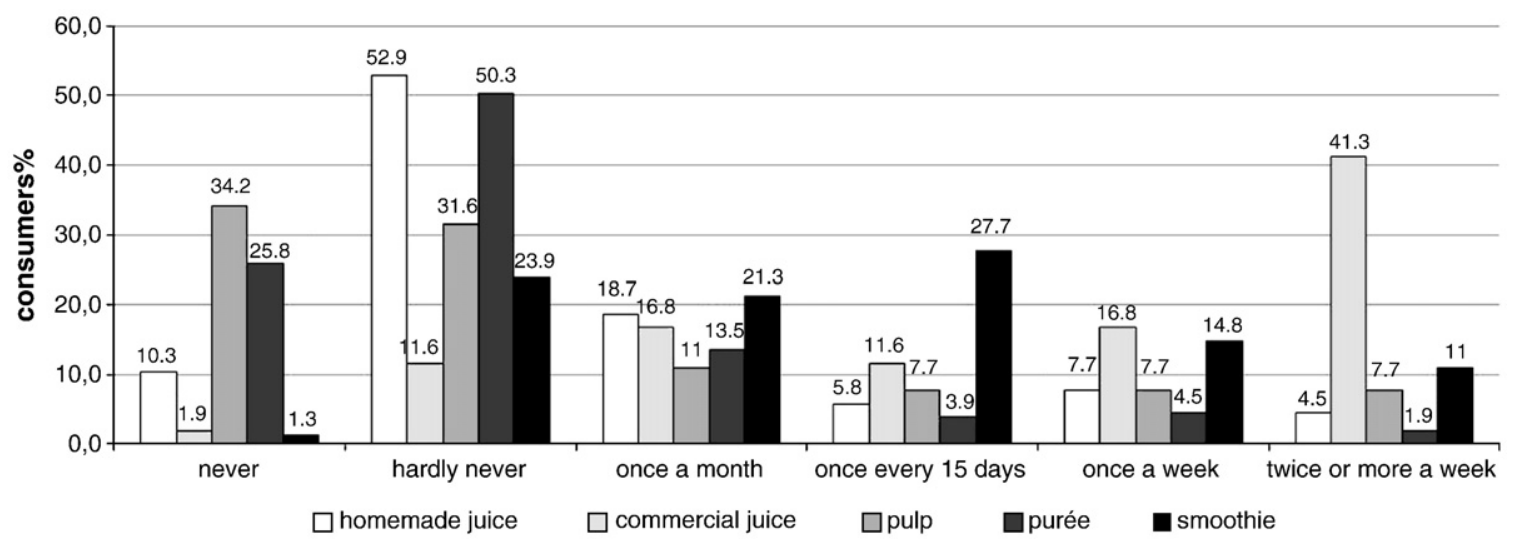

Fig. 3. Frequency intake of the fruit segment products among consumers $(n=155)$.

commercial juices were consumed twice or more a week, and once a week, fruit pulps and purées were hardly ever and never consumed (Fig. 3). Fruit pulps and purées were confirmed as not being product categories considerably well-known and much consumed. Despite the smoothies being liked best and being usually consumed by $75.5 \%$ of participants, few people consumed them very often, suggesting that other factors such as availability and price (Deliza, Rosenthal, Abadio, Silva, \& Castillo, 2005; Enneking, Neumann, \& Henneberg, 2007) may account for a lesser consumption frequency.

Within the fruit based products, consumers were asked to check all that apply on fruit flavors they regularly consumed from a list that included tropical fruit, citrus, berries, "new" fruit like lychee and mangosteen and others. Respondents were also encouraged to write down any other fruit that was not in the list. Orange (76.8\%), strawberry (63.9\%), apple (62.6\%), cranberry (59.4\%), banana (58.7\%), mango (56.1\%), blueberry (53.5\%) and raspberry (51.0\%) were the most enjoyed flavors.

One hundred and thirty consumers (83.9\%) had heard about açaí before this test, and $43.8 \%$ have seen in grocery stores (43.8\%), the internet (was cited by $34.6 \%$ ) and from their friends (30\%). However, $55.5 \%$ had tasted açaí and many of them are in cluster 3 (45.4\%).

Regardless of consumers had tried açaí before, in general, they hardly ever $(66.3 \%)$ or never $(12.8 \%)$ had consumed açaí suggesting that participants might have tasted açaí just as a new experience. Responses about consumers' life style showed that $83.2 \%$ of participants ate organic foods, out of which $77.5 \%$ actually bought organic foods, and most of those consumers were in cluster 3 (chi-square test, $\mathrm{p}=0.042$ ). Many açaí products available in the US market are organic, and for this reason it was worth knowing about participants' consumption of organic food.

Our results corroborated the fact that global organic sales are growing at about 20\% annually in major North American and European markets, and are estimated at roughly US\$20 billion per year (Raynolds, 2004). Previous study in different countries suggested that preference for organics was highest among middle aged wealthy, highly educated females, and people concern about health and the environment (Bellows, Alcaraz, \& Hallman, 2010). In the present research there was a relationship between people who ate organic and level of education (chi-square test results $\mathrm{p}=0.02$ ), as well as being vegetarians and practicing any sport or physical activity (chi-square tests, $\mathrm{p}<0.0001$ ). Some açaí-based samples from this study claimed on labels as being a vegan product. For that reason, it has been identified the vegetarian consumers among the US participants. Among all participants, 12 consumers (7.7\%) were vegetarians, and cluster 2, the group of açaíbased products likers, had the highest percentage of them (11.4\%). Most participants (78.7\%) played a sport or had some physical activity, and cluster 1 - the açaí dislikers - had slightly less consumers that played a sport (71.7\%) than the other segments. However, both findings were not significant (chi-square test, $\mathrm{p}>0.05$ ). Rogez (2000) has also stated that açaí consumers in Southern Brazil usually eat it before or after physical exercises as a manner of recovering energy, vitamins and minerals.

Goldsmith, Freiden, and Henderson (1997) stated that the selection of some food types reflects beliefs about valued ways of being or living and behaviors. Therefore, many health and wellness habits are consumers' choice in order to seek a better way of living.

Açaí properties statements were used to evaluate consumers' knowledge about it (Table 6). Considering scores 1,2 or 3 as disagreement with the statement and 5, 6 and 7 as agreement, results show that $66.4 \%$ of participants agreed they did not know the proprieties of açaí; 79.4\% agreed on açaí being an exotic fruit from the Amazon (60.0\%) and $85.8 \%$ on being a natural food. Consumers agreed on açaí being a healthy (83.2\%) and nutritive food (83.2\%), rich in vitamins and minerals (74.2\%), and a good source of energy (60\%). All the above perceptions were scientifically discussed (Del Pozo-Insfran et al., 2004; Lichtenthäler et al., 2005; Menezes, Thiele, \& Sabaa Srur, 2008; Neida \& Elba, 2007; Schauss, Wu, Prior, Ou, Huang, et al., 2006). Nevertheless, only $25.8 \%$ agreed on açaí being high in calories, $42.6 \%$ on being high in fiber. Indeed, açaí is a fruit high in calories due to its fat content (Nascimento, Couri, Antoniassi, \& Freitas, 2008; Pacheco-Palencia, Mertens-Talcott, \& Talcott, 2008) and rich in fiber, especially soluble fiber (Oliveira, Carvalho, Nascimento, \& Müller, 2002; Yuyama et al., 2004). Many consumers disagreed (77.3\%) that açaí is oily/greasy. Açaí pulps sensory profiles were evaluated in Brazil (Menezes, Deliza, Freitas, \& Rosenthal, 2009) and one characteristic of the product was the greasy attribute, which was considered positive, and a determinant of quality.

Participants agreed that açaí is rich in antioxidants (87.1\%), but surprisingly only $45.2 \%$ of participants agreed that açaí can prevent degenerative diseases, and 51\% neither agree nor disagree on that, suggesting they did not know the antioxidants' role in human health and its association with disease prevention (Kuskoski, Asuero, Morales, \& Fett, 2006; Lichtenthäler et al., 2005; Pacheco-Palencia et al., 2009; Schauss, Wu, Prior, Ou, Huang, et al., 2006; Wang, Melnyk, Tsao, \& Marcone, 2011).

Almost half of the individuals (56.1\%) agreed that açaí is an expensive food, and $42.6 \%$ neither agreed nor disagreed with that statement. The uncertainty about the price could be because they were not regular buyers of açaí products, making it more difficult to judge whether it is expensive or not. As expected, opposite results were found in Brazil (Menezes, Unpublished results).

Factor analysis demonstrated an explained variance of 35.3\%, which was low but expected, since data came from consumers, who have different views of the investigated variables. In general, means scores for the statements among segments did not vary, except from cluster 1, the group of açaí dislikers that had lower averages for açaí being an exotic fruit and a healthy food than clusters 2 and 3 . Also, regarding açaí being 
Table 6

Mean scores for the statements about açaí included in the attitudinal questionnaire.

\begin{tabular}{|c|c|c|c|c|c|}
\hline \multirow[t]{2}{*}{ Statements ${ }^{*}$} & \multirow{2}{*}{$\frac{\text { Total }}{\mathrm{n}=155}$} & \multirow{2}{*}{$\frac{\text { Cluster } 1}{\mathrm{n}=46}$} & \multirow{2}{*}{$\frac{\text { Cluster } 2}{\mathrm{n}=44}$} & \multirow{2}{*}{$\frac{\text { Cluster } 3}{\mathrm{n}=65}$} & \multirow[t]{2}{*}{ Factor loading } \\
\hline & & & & & \\
\hline 1. I do not know the proprieties of açaí. & $5.1 \pm 1.9$ & $5.2^{\mathrm{a}} \pm 2.0$ & $5.1^{\mathrm{a}} \pm 2.1$ & $5.0^{\mathrm{a}} \pm 1.8$ & 0.59 \\
\hline 2. Açaí is an exotic fruit. & $5.7 \pm 1.3$ & $5.3^{\mathrm{b}} \pm 1.4$ & $5.9^{\mathrm{a}} \pm 1.2$ & $6.0^{\mathrm{a}} \pm 1.2$ & 0.87 \\
\hline 3. Açaí is a caloric food. & $3.9 \pm 1.6$ & $4.0^{\mathrm{a}} \pm 1.4$ & $4.2^{\mathrm{a}} \pm 1.6$ & $3.6^{\mathrm{a}} \pm 1.8$ & 0.78 \\
\hline 4. Açaí is a healthy food. & $5.9 \pm 1.2$ & $5.6^{\mathrm{b}} \pm 1.3$ & $5.9^{\mathrm{a}, \mathrm{b}} \pm 1.1$ & $6.2^{\mathrm{a}} \pm 1.1$ & 0.44 \\
\hline 5. Açaí makes you gain weight. & $2.8 \pm 1.4$ & $2.8^{\mathrm{a}} \pm 1.4$ & $3.0^{\mathrm{a}} \pm 1.5$ & $2.6^{\mathrm{a}} \pm 1.4$ & 0.58 \\
\hline 6. Açaí is nutritive. & $5.8 \pm 1.2$ & $5.6^{\mathrm{b}} \pm 1.3$ & $5.7^{\mathrm{a}, \mathrm{b}} \pm 1.2$ & $6.1^{\mathrm{a}} \pm 1.0$ & 0.34 \\
\hline 7. Açaí is a good source of energy & $5.1 \pm 1.2$ & $5.0^{\mathrm{a}} \pm 1.1$ & $5.0^{\mathrm{a}} \pm 1.2$ & $5.4^{\mathrm{a}} \pm 1.3$ & 0.60 \\
\hline 8. Açaí is a food rich in vitamins and minerals. & $5.6 \pm 1.2$ & $5.3^{\mathrm{b}} \pm 1.3$ & $5.6^{\mathrm{a}, \mathrm{b}} \pm 1.2$ & $5.8^{\mathrm{a}} \pm 1.1$ & 0.30 \\
\hline 9. Açaí is a food rich in iron. & $4.2 \pm 1.1$ & $4.2^{\mathrm{a}} \pm 1.1$ & $4.1^{\mathrm{a}} \pm 1.3$ & $4.2^{\mathrm{a}} \pm 1.1$ & 0.37 \\
\hline 10. Açaí is greasy. & $2.1 \pm 1.3$ & $1.9^{\mathrm{a}} \pm 1.2$ & $2.0^{\mathrm{a}} \pm 1.2$ & $2.2^{\mathrm{a}} \pm 1.5$ & 0.82 \\
\hline 11. Açaí is rich in antioxidants. & $6.1 \pm 1.1$ & $6.0^{\mathrm{a}} \pm 1.2$ & $6.1^{\mathrm{a}} \pm 1.2$ & $6.3^{\mathrm{a}} \pm 1.0$ & 0.31 \\
\hline 12. Açaí is a food from the Amazon. & $5.3 \pm 1.3$ & $5.1^{\mathrm{a}} \pm 1.3$ & $5.3^{\mathrm{a}} \pm 1.4$ & $5.4^{\mathrm{a}} \pm 1.3$ & 0.70 \\
\hline 13. Açaí is a natural food. & $6.0 \pm 1.2$ & $5.6^{\mathrm{b}} \pm 1.2$ & $6.2^{\mathrm{a}} \pm 1.2$ & $6.1^{\mathrm{a}} \pm 1.1$ & 0.30 \\
\hline 14. Açaí is high in fiber. & $4.6 \pm 1.3$ & $4.5^{\mathrm{a}} \pm 1.4$ & $4.6^{\mathrm{a}} \pm 1.3$ & $4.8^{\mathrm{a}} \pm 1.2$ & 0.52 \\
\hline 15. Açaí can help prevent degenerative diseases. & $4.8 \pm 1.2$ & $4.7^{\mathrm{a}} \pm 1.2$ & $4.7^{\mathrm{a}} \pm 1.2$ & $5.1^{\mathrm{a}} \pm 1.2$ & 0.60 \\
\hline 16. Açaí is an expensive food. & $5.1 \pm 1.2$ & $5.0^{\mathrm{a}} \pm 1.3$ & $5.1^{\mathrm{a}} \pm 1.2$ & $5.2^{\mathrm{a}} \pm 1.6$ & 0.55 \\
\hline $\begin{array}{l}\text { 17. Açaí is a food that can be consumed by } \\
\text { people from any age: children, teenagers, } \\
\text { adults and elderly. }\end{array}$ & $5.9 \pm 1.2$ & $5.9^{\mathrm{a}} \pm 1.2$ & $4.0^{\mathrm{a}} \pm 1.2$ & $5.9^{\mathrm{a}} \pm 1.2$ & 0.63 \\
\hline
\end{tabular}

Means in the same row followed by different letters imply a significant difference ( $\mathrm{p} \leq 0.05$ ) according to LSD test between clusters.

* Evaluated in a 7-point interval scale ( $1=$ totally disagree; $4=$ neither disagree, nor agree; $7=$ totally agree).

nutritive and rich in vitamins and minerals, that same group had shown statistically different $(\mathrm{p}<0.05)$ means from cluster 3 , comprising the higher percentage of participants that already tasted açaí.

\subsection{Effects of food neophobia (FN)}

Foods from other countries are crossing the traditional borders of national culture due to globalization, and the concept of food neophobia has been extensively used to investigate willingness to try unfamiliar ethnic foods (Pliner \& Hobden, 1992) and use functional foods (Urala \& Lähteenmäki, 2007). Some novelties evoke resistance and doubts, whereas others are welcomed more easily as part of the daily eating routine (Bäckström et al., 2004). In our study, $67.7 \%$ of the consumers had low food neophobia $(n=105)$ and only $7.7 \%$ were highly neophobic $(n=12)$. It may imply that participants were not reluctant to try novel or unfamiliar foods, and among clusters, no difference was observed (chi-square test, $\mathrm{p}=0.256$ ). We can speculate that extreme neophobics would not even sign up for an açaí test (Arvola, Lähteenmäki, \& Tuorila, 1999; Henriques et al., 2009; Tuorila, Meiselman, Bell, Cardello, \& Johnson, 1994).

Food neophobia results are presented in Table 7. The variance was explained by $44.4 \%$ of data. Mean scores among segments have not shown statistical difference $(\mathrm{p}<0.05)$, except from cluster 1 who presented a higher average for one of the statements suggesting that they are constantly sampling new and different food slightly more than consumers in clusters 2 and 3. Consumer tendency to avoid novel foods may affect the acceptance of unfamiliar or novel products (Nasser El Dine \& Olabi, 2009). For this reason, average scores for liking and purchase intention between low FN and high FN consumers were compared using ANOVA.

Overall liking, flavor liking and purchase intent mean scores for some açaí-based products were significantly higher for the low FN consumers than for the high FN individuals. Similar findings were reported by Sabbe et al. (2009b) and Arvola et al. (1999), who analyzed other variables (e.g. attitudes, intent and taste pleasantness) related to neophobia. They observed that there was an apparent tendency for neophobics ( high FN) to react more negatively, especially towards novel foods. On the other hand, products A and smoothies (D1 and D2) showed no significant differences between low and high FN groups.

Despite some consumers had already tasted açaí before, this fruit is not familiar for North Americans. So, a possible familiarity, which could decrease food neophobia (Bäckström et al., 2004; Henriques et al., 2009; Pliner \& Hobden, 1992; Raudenbush \& Frank, 1999) was not sufficiently able to do so. Perhaps, açaí consumption might have been a single experience for such individuals, not a regular habit. Different mechanisms may regulate the choice of novel and familiar foods (Flight et al., 2003). Arvola et al. (1999) assumed that familiar food may be chosen more often through force of habit, and a novel food is avoided due to a general conservative tendency. The literature indicates that tasting (Tuorila et al., 1994), previous familiarity (Birch, 1979) or familiarity created by repeated exposure to initially novel foods (Pliner, 1982; Sullivan \& Birch, 1990) usually increase preference for a particular product. Thus, the present study revealed no relationship between FN and had tried açaí before (chi-square test, $\mathrm{p}>0.05$ ).

\subsection{Effects of general health interest (GHI)}

In general, public interest in healthy eating has increased due to the high incidence of disorders linked to food intake, such as obesity, cancer and cardiovascular diseases (WHO, 2004). Previous studies have also shown health to be an important factor affecting food choice (Roininen et al., 1999; Steptoe et al., 1995). General health interest results are presented in Table 7 (the variance accounted for by 54\%), 51\% of participants showed a high interest in eating healthily, 35.5\% a medium and $13.5 \%$ a low interest. According to Verbeke (2005), people with high general health interest are found to be more willing to compromise on taste for a perceived nutritional and health benefit, than people with low general health interest. Mean acceptance values for açaí-based products did not differ statistically between low GHI and high GHI level groups, which mean that no matter the consumer health interest; both groups seemed to have appreciated the most liked products, sorbet, smoothie D1 and juice B1. Similar results were observed for purchase intention.

General health orientation varies systematically as a function of age and gender (Roininen et al., 2001; Verbeke, 2005). The chi-square test had shown no relationship between GHI and age, but there was between consumers who ate smoothie and $\mathrm{GHI}(\mathrm{p}=0.007)$ and, between gender and GHI $(p=0.052)$ with women having a higher GHI than men. This finding is in agreement with the results of Steptoe and Wardle (1992) and Wardle and Steptoe (1991) who showed "healthier" behavior patterns for females than males. No relationship was found between clusters and GHI (chi-square test, $\mathrm{p}=0.925$ ), even though there were more women in clusters 1 and 2.

\subsection{Attitude towards functional foods}

Table 7 presents the average scores for the functional foods statements. Factor analysis revealed an explained variance of $35.4 \%$, 
Table 7

Results (means \pm SD) of Food Neophobia, General Health Interest, and Functional Food Scales*.

\begin{tabular}{|c|c|c|c|c|c|}
\hline \multirow[t]{2}{*}{ Statements } & \multirow{2}{*}{$\frac{\text { Total }}{\mathrm{n}=155}$} & \multirow{2}{*}{$\frac{\text { Cluster } 1}{\mathrm{n}=46}$} & \multirow{2}{*}{$\frac{\text { Cluster } 2}{\mathrm{n}=44}$} & \multirow{2}{*}{$\frac{\text { Cluster } 3}{\mathrm{n}=65}$} & \multirow[t]{2}{*}{ Factor loading } \\
\hline & & & & & \\
\hline \multicolumn{6}{|l|}{ Food neophobia } \\
\hline 1. I am constantly sampling new and different foods. (R) & $3.0 \pm 1.8$ & $3.6^{\mathrm{a}} \pm 2.1$ & $2.7^{\mathrm{b}} \pm 1.4$ & $2.7^{\mathrm{b}} \pm 1.7$ & 0.77 \\
\hline 2. I do not trust new foods. & $2.2 \pm 1.4$ & $2.5^{\mathrm{a}} \pm 1.5$ & $2.0^{\mathrm{a}} \pm 1.2$ & $2.3^{\mathrm{a}} \pm 1.3$ & 0.10 \\
\hline 3. If I do not know what a food is, I will not try it. & $2.4 \pm 1.7$ & $2.8^{\mathrm{a}} \pm 2.0$ & $2.0^{\mathrm{a}} \pm 1.4$ & $2.3^{\mathrm{a}} \pm 1.7$ & 0.76 \\
\hline 4. I like foods from different cultures. (R) & $1.7 \pm 1.0$ & $1.9^{\mathrm{a}} \pm 1.4$ & $1.6^{\mathrm{a}} \pm 0.7$ & $1.5^{\mathrm{a}} \pm 0.9$ & 0.41 \\
\hline 5. Ethnic foods look too weird to eat. & $1.7 \pm 1.2$ & $1.9^{\mathrm{a}} \pm 1.4$ & $1.6^{\mathrm{a}} \pm 1.0$ & $1.7^{\mathrm{a}} \pm 1.1$ & 0.53 \\
\hline 6. At dinner parties, I will try new foods. (R) & $1.6 \pm 0.9$ & $1.8^{\mathrm{a}} \pm 1.0$ & $1.7^{\mathrm{a}} \pm 0.9$ & $1.5^{\mathrm{a}} \pm 0.8$ & 0.38 \\
\hline 7. I am afraid to eat things I have never had before. & $1.9 \pm 1.4$ & $2.0^{\mathrm{a}} \pm 1.5$ & $1.7^{\mathrm{a}} \pm 1.1$ & $2.0^{\mathrm{a}} \pm 1.4$ & 0.50 \\
\hline 8. I am very particular about the foods I eat. & $3.7 \pm 1.9$ & $3.6^{\mathrm{a}} \pm 1.8$ & $4.0^{\mathrm{a}} \pm 1.8$ & $3.6^{\mathrm{a}} \pm 1.9$ & 0.63 \\
\hline 9. I will eat almost anything. (R) & $3.4 \pm 2.0$ & $3.3^{\mathrm{a}} \pm 1.9$ & $3.3^{\mathrm{a}} \pm 1.9$ & $3.6^{\mathrm{a}} \pm 2.0$ & 0.12 \\
\hline 10. I like to try new restaurants. (R) & $1.6 \pm 0.9$ & $1.7^{\mathrm{a}} \pm 0.9$ & $1.5^{\mathrm{a}} \pm 0.7$ & $1.6^{\mathrm{a}} \pm 0.9$ & 0.69 \\
\hline \multicolumn{6}{|l|}{ General health interest } \\
\hline 1. I am very particular about the healthiness of food. & $5.2 \pm 1.5$ & $5.1^{\mathrm{a}} \pm 1.7$ & $5.2^{\mathrm{a}} \pm 1.4$ & $5.3^{\mathrm{a}} \pm 1.3$ & 0.39 \\
\hline 2. I always follow a healthy and balanced diet. & $4.5 \pm 1.5$ & $4.3^{\mathrm{a}} \pm 1.7$ & $4.6^{\mathrm{a}} \pm 1.4$ & $4.5^{\mathrm{a}} \pm 1.5$ & 0.42 \\
\hline 3. It is important for me that my diet is low in fat. & $4.5 \pm 1.8$ & $4.4^{\mathrm{a}} \pm 1.9$ & $4.6^{\mathrm{a}} \pm 1.8$ & $4.5^{\mathrm{a}} \pm 1.6$ & 0.70 \\
\hline $\begin{array}{l}\text { 4. It is important for me that my daily diet contains a } \\
\text { lot of vitamins and minerals. }\end{array}$ & $5.5 \pm 1.4$ & $5.3^{\mathrm{a}} \pm 1.6$ & $5.8^{\mathrm{a}} \pm 1.3$ & $5.4^{\mathrm{a}} \pm 1.4$ & 0.47 \\
\hline $\begin{array}{l}\text { 5. I eat what I like and I do not worry about the healthiness } \\
\text { of food. (R) }\end{array}$ & $4.9 \pm 1.7$ & $3.2^{\mathrm{ab}} \pm 1.8$ & $2.7^{\mathrm{b}} \pm 1.7$ & $3.4^{\mathrm{a}} \pm 1.7$ & 0.31 \\
\hline $\begin{array}{l}\text { 6. The healthiness of food has little impact on my food } \\
\text { choices. }(R)\end{array}$ & $5.4 \pm 1.6$ & $2.6^{\mathrm{a}} \pm 1.8$ & $2.7^{\mathrm{a}} \pm 1.7$ & $2.5^{\mathrm{a}} \pm 1.4$ & 0.37 \\
\hline $\begin{array}{l}\text { 7. The healthiness of snacks makes no differences for } \\
\text { me. (R) }\end{array}$ & $5.5 \pm 1.6$ & $2.7^{\mathrm{a}} \pm 1.8$ & $2.4^{\mathrm{a}} \pm 1.4$ & $2.5^{\mathrm{a}} \pm 1.4$ & 0.30 \\
\hline $\begin{array}{l}\text { 8. I do not avoid any foods, even if they may raise my } \\
\text { cholesterol. (R) }\end{array}$ & $5.0 \pm 1.8$ & $2.8^{\mathrm{ab}} \pm 1.8$ & $2.6^{\mathrm{b}} \pm 1.7$ & $3.5^{\mathrm{a}} \pm 1.8$ & 0.71 \\
\hline \multicolumn{6}{|l|}{ Functional foods } \\
\hline 1. I get pleasure from eating functional foods. & $5.5 \pm 1.3$ & $5.6^{\mathrm{a}} \pm 1.3$ & $5.5^{\mathrm{a}} \pm 1.4$ & $5.6^{\mathrm{a}} \pm 1.3$ & 0.51 \\
\hline 2. I actively seek out information about functional foods. & $4.7 \pm 1.7$ & $4.8^{\mathrm{a}} \pm 1.8$ & $4.5^{\mathrm{a}} \pm 1.9$ & $4.7^{\mathrm{a}} \pm 1.6$ & 0.38 \\
\hline 3. I willingly try even unfamiliar products if they are functional. & $5.2 \pm 1.5$ & $5.3^{\mathrm{a}} \pm 1.3$ & $5.0^{\mathrm{a}} \pm 1.7$ & $5.3^{\mathrm{a}} \pm 1.4$ & 0.50 \\
\hline 4. I trust the information given about health effects. & $4.5 \pm 1.5$ & $4.5^{\mathrm{a}} \pm 1.5$ & $4.3^{\mathrm{a}} \pm 1.5$ & $4.5^{\mathrm{a}} \pm 1.5$ & 0.43 \\
\hline 5. I believe that functional foods fulfill their promises. & $4.3 \pm 1.4$ & $4.1^{\mathrm{a}} \pm 1.4$ & $4.4^{\mathrm{a}} \pm 1.4$ & $4.3^{\mathrm{a}} \pm 1.4$ & 0.26 \\
\hline 6. Exaggerated information is given about health effects. (R) & $3.1 \pm 1.2$ & $5.3^{\mathrm{a}} \pm 1.4$ & $4.7^{\mathrm{b}} \pm 1.0$ & $4.9^{\mathrm{ab}} \pm 1.1$ & 0.96 \\
\hline 7. I can promote my health by consuming functional foods. & $5.5 \pm 1.2$ & $5.4^{\mathrm{a}} \pm 1.3$ & $5.7^{\mathrm{a}} \pm 1.0$ & $5.5^{\mathrm{a}} \pm 1.2$ & 0.08 \\
\hline 8. Functional foods are completely unnecessary. (R) & $5.7 \pm 1.2$ & $2.3^{\mathrm{a}} \pm 1.2$ & $2.2^{\mathrm{a}} \pm 1.2$ & $2.4^{\mathrm{a}} \pm 1.3$ & 0.51 \\
\hline 9. I can prevent disease by eating functional foods regularly. & $4.9 \pm 1.5$ & $4.8^{\mathrm{a}} \pm 1.6$ & $5.2^{\mathrm{a}} \pm 1.2$ & $4.9^{\mathrm{a}} \pm 1.5$ & 0.52 \\
\hline $\begin{array}{l}\text { 10. I do not believe that functional foods will ensure a long and } \\
\text { healthy life for me. (R) }\end{array}$ & $5.0 \pm 1.6$ & $3.1^{\mathrm{a}} \pm 1.8$ & $2.8^{\mathrm{a}} \pm 1.4$ & $3.3^{\mathrm{a}} \pm 1.6$ & 0.41 \\
\hline $\begin{array}{l}\text { 11. For me, good taste is more important than health effects in } \\
\text { a food product. }(\mathrm{R})\end{array}$ & $4.3 \pm 1.5$ & $3.5^{\mathrm{a}} \pm 1.4$ & $3.6^{\mathrm{a}} \pm 1.5$ & $3.8^{\mathrm{a}} \pm 1.6$ & 0.80 \\
\hline $\begin{array}{l}\text { 12. I am prepared to compromise on the taste of a food if the } \\
\text { product is functional. }\end{array}$ & $4.3 \pm 1.6$ & $4.1^{\mathrm{a}} \pm 1.7$ & $4.4^{a} \pm 1.6$ & $4.4^{a} \pm 1.5$ & 0.77 \\
\hline $\begin{array}{l}\text { 13. I do not buy functional foods unless I know how they } \\
\text { taste. (R) }\end{array}$ & $4.1 \pm 1.6$ & $4.2^{\mathrm{a}} \pm 1.6$ & $4.2^{\mathrm{a}} \pm 1.7$ & $3.8^{\mathrm{a}} \pm 1.3$ & 0.95 \\
\hline
\end{tabular}

$\mathrm{SD}=$ standard deviation.

Negative worded statement marked with (R) was reversed for analyses.

Means in the same row followed by different letters imply a significant difference ( $p \leq 0.05)$ according to LSD test between clusters.

* Evaluated in a 7 point interval scale ( $1=$ totally disagree; $4=$ neither disagree, nor agree; $7=$ totally agree).

which was expectedly low considering that participants had different opinions about these variables studied. In general, the analyses of variance performed on clusters' data did not show any statistical difference. Consumers' responses regarding the functional food statements revealed that $76.8 \%$ of participants agreed (scores 5,6 and 7 of a 7 points scale) that eating functional food would give them pleasure, but not as much (58.7\%) agreed that they are actively seeking out information about functional foods. The majority of participants (75.5\%) agreed on willingly to try even unfamiliar products if they were functional, corroborating with the fact that most consumers in this study are neophilics and have shown high health interest.

More than half of participants (54.8\%) trust the information about health effect of functional foods and $44.5 \%$ believed that functional foods fulfilled their promises whereas 29.7\% neither agree, nor disagree. Similarly, West, Gendron, Larue, and Lambert (2002) found that Canadian consumers believe in a strong relationship between food choice and disease prevention, and Schmidt (2000 apud Teratanavat \& Hooker, 2006) reported from a telephone survey that more than $95 \%$ of consumers believed that certain foods have benefits that go beyond basic nutrition and may reduce the risk of certain diseases or improve their overall health. Notwithstanding, $30.3 \%$ of the consumers in our study disagreed on that, suggesting a suspicious attitude towards possible harmful effects of functional foods, as stated by Urala and Lähteenmäki (2007).

For the English consumers, the main reason for distrusting functional foods was the lack of familiarity and knowledge about what these products really are, and the ingredients to make them up (Newsholme, 2002). Hence, similar reasons might have had participants in the present study who distrusted the information about health effects of functional food.

American consumers (81.9\%) agreed that they can improve their health by consuming functional foods, however not as much (65.8\%) agreed with functional foods being able to prevent disease by eating it regularly, and $65.2 \%$ do not believe functional foods will ensure a long and healthy life. In general, consumers think that functional foods are completely unnecessary ( $81.9 \%$ ), but on the other hand only $9.7 \%$ agreed that exaggerated information is given about health effects.

Consumers simply do not consider the general necessity as a reason behind their personal willingness to use functional food products (Urala 
\& Lähteenmäki, 2007) and that might be the reason why functional foods were evaluated as completely unnecessary by participants in this study. Barrios et al. (2008) explored the attitudes towards functional foods with Spanish consumers, and revealed that they did not consider the products necessary if one has good eating habits. They also believed that this type of product is surrounded by too much advertising and they only exist in the market as a marketing strategy to increase sales.

When asking individuals about taste of the functional foods, $49.7 \%$ agreed that good taste is more important than health effects in a food product, whereas $29.7 \%$ disagreed on that and $52.3 \%$ were prepared to compromise on the taste if the product is functional. Almost $43 \%$ of consumers agreed that they do not buy functional foods unless they know how they taste, and 36.1\% disagreed on that.

Consumers proved to be skeptical about buying a functional product without knowing how it tastes, especially when açaí was in the product formulation. Price might be also associated with those responses, since a number of previous empirical studies have also identified the premium price for functional foods as a major hurdle to acceptance and buying intention (Verbeke, 2005). Thus, this might be a relevant consideration because the majority of the respondents are students and have an annual income lower than US\$50,000.00. On the other hand, $36.1 \%$ buy functional foods even without knowing the product taste.

Barrios et al. (2008) concluded that the lack of knowledge on some functional food ingredients, the price, lack of confidence in their physiological effects and in the marketing messages were identified as the main reasons why many consumers are reluctant to buy them. Somehow these findings are in agreement with this açaí study results.

\section{Conclusion}

This study contributed to the understanding of preferences and attitudes of North American consumers towards açaí-based products. Consumers' preferences were driven by flavor and aftertaste, whereas the sorbet, juice and smoothie were among the most appreciated products. Internal preference mapping and cluster analysis have demonstrated different preference patterns among North American consumers, identifying açaí likers and dislikers, as well as variation on demographic characteristics. Some participants had already tasted açaí before the study, but previous exposure to açaí products did not make any effect on consumers' preferences. As a novel functional product, it was suspected that people with reluctance to try new products would react differently towards açaí but no effect was observed on acceptance.

The results were encouraging and allowed one to discern distinctly that there is a possible market for açaí-based products in young or older, female, food neophilic and health-conscious consumers. Products such as sorbet and juices may be promising alternatives to the Californian market.

In general, participants demonstrated lack of knowledge about açaí, mainly related to its composition and health-promoting benefits even though they were aware it is rich in antioxidants and a healthy food. Attitude towards functional foods demonstrated consumers have pleasure on consuming functional foods and that they are attempt to try unfamiliar products if they are functional. Partially, North Americans revealed an interest in comprising on taste for functional foods but others declared that good taste is more important than health effects in a food product.

Despite the important findings that brought initial insights related to functional food and its carriers, considering different categories of açaí products, the study faced certain limitations as a narrow variety of açaí products in some food categories, the presence of other ingredients in the açaí based product formulations which may have contributed to sensory differences among products and, consequently, affecting consumer liking and lastly, the missing açaí content information on product labels. Such observations may had lead to a not completely clear understanding of consumer preferences, demanding further research to provide a better comprehension of the preferred identified categories and the way consumers would like to have açaí. Moreover, it should comprise other product features that may influence consumers' acceptance, such as health claims, packaging characteristics and price. Familiarity and repeated exposure trials to evaluate consumers' preferences is also recommended to be considered.

\section{Acknowledgments}

Special thanks to Coordenação de Aperfeiçoamento de Pessoal de Nível Superior (CAPES) for the PDEE Scholarship granted to Ellen Menezes. Also, to the lab assistants and colleagues, students at the Food Science \& Technology, UCDavis, the Project Management Consultant Mauro Ayres Jr., Açaí Companies and all consumers who participated in this study.

\section{References}

Almeida, M. B. D., Zoellner, S. S., Cruz, A. G. D., Moura, M. R. L., Carvalho, L. M. J. D. Freitas, M. C. J., et al. (2008). Potentially probiotic açaí yogurt. International Journa of Dairy Technology, 62(2), 178-182.

Ares, G., Barreiro, C., Deliza, R., \& Gámbaro, A. (2009). Alternatives to reduce the bitterness, astringency and characteristic flavor of antioxidant extracts. Food Research International, 42, 871-878.

Ares, G., \& Gámbaro, A. (2007). Influence of gender, age and motives underlying food choice on perceived healthiness and willingness to try functional foods. Appetite $49,148-158$.

Ares, G., Giménez, A., \& Gámbaro, A. (2008). Understanding consumers' perception of conventional and functional yogurts using word association and laddering. Food Quality and Preference, 19, 636-643.

Arvola, A., Lähteenmäki, L., \& Tuorila, H. (1999). Predicting the intent to purchase unfamiliar and familiar cheeses: The effects of attitudes, expected liking and food neophobia. Appetite, 32, 113-126.

Bäckström, A., Pirttilä-Backman, A. M., \& Tuorila, H. (2004). Willingness to try new foods as predicted by social representations and attitude and trait scales. Appetite 43, 75-83.

Barrios, E. X., Bayarri, S., Carbonell, I., Izquierdo, L., \& Costell, E. (2008). Consumer attitudes and opinions toward functional foods: A focus group study. Journal of Sensory Studies, 23, 514-525.

Bayarri, S., Carbonell, I., Barrios, E., \& Costell, E. (2011). Impact of sensory differences on consumer acceptability of yogurt and yogurt-like products. International Dairy Journal, 21, 111-118.

Bech-Larsen, T., \& Scholderer, J. (2007). Functional foods in Europe: Consumer research, market experiences and regulatory aspects. Trends in Food Science and Technology $18,231-234$

Bellows, A. C., Alcaraz, G. V., \& Hallman, W. K. (2010). Gender and food, a study of attitudes in the USA towards organic, local, U.S. grown, and GM-free foods. Appetite, $55,540-550$.

Birch, L. L. (1979). Dimensions of pre-school children's food preferences. Journal of Nutrition Education, 11, 77-80.

Bobbio, F. O., Druzian, J. I., Abrão, P. A., Bobbio, P. A., \& Fadelli, S. (2000). Identificação e quantificação das antocianinas do fruto do açaizeiro (Euterpe oleracea) Mart Ciência e Tecnologia de Alimentos, 20(3), 388-390.

Bower, J. A., Saadat, M. A., \& Whitten, C. (2003). Effect of liking, information and consumer characteristics on purchase intention and willingness to pay more for a fat spread with a proven health benefit. Food Quality and Preference, 14, 65-74.

Brondizio, E. S. (2008). The Amazonian caboclo and the açai palm. Forest Farmers in the global market (1st ed.). . New York: New York Botanical Garden Press 318 pp.

Brondizio, E., Safar, C., \& Siqueira, A. (2002). The urban market of açaí fruit (Euterpe oleracea Mart.) and rural land use change: Ethnographic insights into the role of price and land tenure constraining agricultural choices in the Amazon estuary. Urban Ecosystems, 6, 67-97.

Carbonell, L., Bayarri, S., Navarro, J. L., Carbonell, I., \& Izquierdo, L. (2009). Sensory profile and acceptability of juices from Mandarin varieties and hybrids. Food Science and Technology International, 15(4), 375-385.

Coïsson, J. D., Travaglia, F., Piana, G., Capasso, M., \& Arlorio, M. (2005). Euterpe oleracea juice as a functional pigment for yogurt. Food Research International, 38, 893-897.

Cox, D. N., Koster, A., \& Russell, C. G. (2004). Predicting intentions to consume functional foods and supplements to offset memory loss using an adaptation if protection motivation theory. Appetite, 43, 55-64.

Cronbach, L. J. (1951). Coefficient alpha and the internal structure of tests. Psychometrika, $16,297-334$

Del Pozo-Insfran, D., Brenes, C. H., \& Talcott, S. T. (2004). Phytochemical composition and pigment stability of açaí (Euterpe oleracea Mart.). Journal of Agricultural and Food Chemistry, 52, 1539-1545.

Del Pozo-Insfran, D., Percival, S. S., \& Talcott, S. T. (2006). Açaí (Euterpe oleracea Mart.) polyphenolics in their glycoside and aglycone forms induce apoptosis of HL-60 leukemia cells. Journal of Agricultural and Food Chemistry, 54, 1222-1229.

Deliza, R., Rosenthal, A., Abadio, F. B. D., Silva, C. H. O., \& Castillo, C. (2005). Application of high pressure technology in the fruit juice processing: Benefits perceived by consumers. Journal of Food Engineering, 67, 241-246. 
Diplock, A. T., Aggett, P. J., Ashwell, M., Bornet, F., Fern, E. B., \& Roberfroid, M. B. (1999) Scientific concepts of functional foods in Europe: Consensus document. The British Journal of Nutrition, 81, S1-S27.

Enneking, U., Neumann, C., \& Henneberg, S. (2007). How important intrinsic and extrinsic product attributes affect purchase decision. Food Quality and Preference, $18,133-138$.

Flight, I., Leppard, P., \& Cox, D. N. (2003). Food neophobia and associations with cultural diversity and socio-economic status amongst rural and urban Australian adolescents. Appetite, 41, 51-59.

Gallori, S., Bilia, A. R., Bergonzi, M. C., Barbosa, W. L. R., \& Vincieri, F. F. (2004) Polyphenolic constituents of fruit pulp of Euterpe oleracea Mart. (açaí palm). Chromatographia, 59, 739-743.

Goldsmith, R. E., Freiden, J., \& Henderson, K. V. (1997). The impact of social values on food-related attitudes. British Food Journal, 99, 352-357.

Greenhoff, K., \& MacFie, H. J. H. (1994). Preference mapping in practice. In H. J. H. MacFie, \& D. M. H. Thomson (Eds.), Measurement of food preferences (pp. 137-166) London: Blackie Academic \& Professional.

Guerrero, L., Guardia, M. D., Xicola, J., Verbeke, W., Vanhonacker, F., Zakowska-Biemans, S., et al. (2009). Consumer-driven definition of traditional food products and innovation in traditional foods. A qualitative cross-cultural study. Appetite, 52, $345-354$.

Guinard, J. -X., Uotani, B., \& Schlich, P. (2001). Internal and external preference mapping of preferences for commercial lager beers: Comparison of hedonic ratings by consumers blind versus with knowledge of brand and price. Food Quality and Preference, $12,243-255$

Hassimotto, N. M. A., Genovese, M. I., \& Lajolo, F. M. (2005). Antioxidant activity of dietary fruits, vegetables, and commercial frozen fruit pulps. Journal of Agricultural and Food Chemistry, 53, 2928-2935.

Henriques, A. S., King, S. K., \& Meiselman, H. L. (2009). Consumer segmentation based on food neophobia and its application to product development. Food Quality and Preference, 20, 83-91.

Jacobsen, T., \& Gunderson, R. W. (1986). Applied clusters analysis. In J. R. Piggot (Ed.) Statistical procedures in food research (pp. 361-408). Glasgow, UK: Elsevier.

Jaeger, S. R., Andani, Z., Wakeling, I. N., \& MacFie, H. J. H. (1998). Consumer preference for fresh and aged apples: A cross-cultural comparison. Food Quality and Preference. 9(5), 355-366.

Jaeger, S. R., Rossiter, K. L., Wismer, W. V., \& Harker, F. R. (2003). Consumer-driven produc development in the kiwi fruit industry. Food Quality and Preference, 14, 187-198.

Jong, N., Ocké, M. C., Branderhorst, H. A. C., \& Friele, R. (2003). Demographic and lifestyle characteristics of functional food consumers and dietary supplement users. The British Journal of Nutrition, 89, 273-281.

Kuskoski, E. M., Asuero, A. G., Morales, M. T., \& Fett, R. (2006). Frutos tropicais silvestres e polpas de frutas congeladas: Atividade antioxidante, polifenóis e antocianinas. Ciência Rural, 36, 1283-1287.

Lähteenmäki, L., Lyly, M., \& Urala, N. (2007). Consumer attitudes towards functiona foods. In L. Frewer, \& H. van Trijp (Eds.), Understanding consumers of food product (pp. 412-427). Cambridge, England: Woodhead Publishing Limited.

Lesschaeve, I., \& Noble, A. C. (2005). Polyphenols: Factors influencing their sensory properties and their effects on food and beverages preferences. The American Journal of Clinical Nutrition, 81, 330S-335S.

Lichtenthäler, R., Belandrino-Rodrigues, R., Maia, J. G. S., Papagiannopoulos, M. Fabricius, H., \& Marx, F. (2005). Total oxidant scavenging capacities of Euterpe oleracea Mart. (Açaí) fruits. International Journal of Food Sciences and Nutrition, 56 (1), 53-64.

Luckow, T., \& Delahunty, C. (2004). Which juice is 'healthier'? A consumer study of probiotic non-dairy juice drinks. Food Quality and Preference, 15, 751-759.

Lyly, M., Roininen, K., Honkapää, K., Poutanen, K., \& Lähteenmäki, L. (2007). Factors influencing consumers' willingness to use beverages and ready-to-eat frozen soups containing oat $\beta$-glucan in Finland, France and Sweden. Food Quality and Preference $18,242-255$

MacFie, H. (2007). Preference mapping and food product development. In H. MacFie (Ed.), Consumer-led food product development (pp. 551-592). Cambridge: Woodhead Publishing Limited.

MacFie, H. J. Bratchell, N., Greenhoff, K., \& Vallis, L. V. (1989). Designs to balance the effect of order of presentation and first-order carry-over effects in hall tests. Journal of Sensory Studies, 4, 129-148.

Meilgaard, M., Civille, G. V., \& Carr, B. T. (1999). Sensory evaluation techniques (3rd ed.) New York: Boca Raton.

Menezes, E. M. S. (Unpublished results). Aceitação e intenção de compra da polpa de açaí por consumidores brasileiros. Relatório de atividades. Embrapa Agroindústria de Alimentos (CTAA)

Menezes, E. M. S., Deliza, R., Freitas, D. G. C., \& Rosenthal, A. (2009). Açaí pulp (Euterpe oleracea, Mart.) sensory profile. Proceedings of the 8th Pangborn Sensory Science Symposium. Florence, Italy: Elsevier.

Menezes, E. M. S., Torres, A. T., \& Sabaa Srur, A. U. (2008). Valor nutricional da polpa de açaí (Euterpe oleracea, Mart.) liofilizada. Acta Amazônica, 38(2), 311-316.

Mertens-Talcott, S. U., Rios, J., Jilma-Stohlawetz, P., Pacheco-Palencia, L. A., Meibohm, B. \& Talcott, S. T. (2008). Pharmacokinetics of anthocyanins and antioxidant effects after the consumption of anthocyanin-rich açaí juice and pulp (Euterpe oleracea Mart.) in human healthy volunteers. Journal of Agricultural and Food Chemistry, 56, 7796-7802.

Mollet, B., \& Rowland, I. (2002). Functional foods: At the frontier between food and pharma. Current Opinion in Biotechnology, 13, 483-485.

Monteleone, E., Frewer, L., Wakeling, I. N., \& Mela, D. J. (1998). Individual differences in starchy food consumption: The application of preference mapping. Food Quality and Preference, 9(4), 11-219.
Moskowitz, H., Reisner, M., Itty, B., Katz, R., \& Krieger, B. (2006). Steps towards a consumer-driven "concept innovation machine" for food and drink. Food Quality and Preference, 17(7-8), 536-551.

Murrieta, R. S. S., Dufour, D. L., \& Siqueira, A. D. (1999). Food consumption and subsistence in three caboclo populations on Marajó Island. Human Ecology, 27, 455-475.

Nascimento, R. J. S., Couri, S., Antoniassi, R., \& Freitas, S. P. (2008). Composição em ácidos graxos do óleo da polpa de açaí extraído com enzimas e com hexano. Revista Brasileira de Fruticultura, 30, 498-502.

Nasser El Dine, A., \& Olabi, A. (2009). Effect of reference foods in repeated acceptability tests. Testing familiar and novel foods using 2 acceptability scales. Journal of Food Science, 74, S97-S106

National Restaurant Association. (2008). Chef Survey: What is hot in 2009. Washington, D.C. http://www.restaurant.org/pdfs/research/2009chefsurvey.pdf last accessed in 02/17/2011.

Neida, S., \& Elba, S. (2007). Characterization of the açaí or manaca (Euterpe oleracea Mart): A fruit of the Amazon. Archivos Latinoamericanos de Nutrición, 57, 94-98.

Newsholme, H. C. (2002). Consumer awareness of and attitudes towards functional foods.: Campden \& Chorleywood Food Research Association Group 45 pp.

O'Mahony, M. (1982). Some assumptions and difficulties with common statistics. Food Technology, 36, 75-82.

Oliveira, M. S. P., Carvalho, J. E. U., Nascimento, W. L. O., \& Müller, C. H. (2002). Cultivo do Açaizeiro para Produção de Frutos. Circular Técnico. Embrapa Amazônia Oriental, 26, $1-18$.

Pacheco-Palencia, L. A., Duncan, C. E., \& Talcott, S. T. (2009). Phytochemical composition and thermal stability of two commercial açai species, Euterpe oleracea and Euterpe precatoria. Food Chemistry, 115, 1199-1205.

Pacheco-Palencia, L. A., Hawken, P., \& Talcott, S. T. (2007). Phytochemical, antioxidant and pigment stability of açaí (Euterpe oleracea Mart.) as affected by clarification, ascorbic acid fortification and storage. Food Research International, 40, 620-628.

Pacheco-Palencia, L. A., Mertens-Talcott, S., \& Talcott, S. T. (2008). Chemical composition, antioxidant properties, and thermal stability of a phytochemical enriched oil from açaí (Euterpe oleracea Mart.). Journal of Agricultural and Food Chemistry, 56, 4631-4636.

Pliner, P. (1982). The effects of mere exposure on liking for edible substances. Appetite, 3, 283-290.

Pliner, P., \& Hobden, K. (1992). Development of a scale to measure the trait of food neophobia in humans. Appetite, 19, 105-120.

Pompeu, D. R., Silva, E. M., \& Rogez, H. (2009). Optimisation of the solvent extraction of phenolic antioxidants from fruits of Euterpe oleracea using Response Surface Methodology. Bioresource Technology, 100, 6076-6082

Raudenbush, B., \& Frank, R. A. (1999). Assessing food neophobia: The role of stimulus familiarity. Appetite, 32, 261-271.

Raynolds, L. T. (2004). The globalization of organic agro-food networks. World Development, 32, 725-743.

Rocha, A. P., Carvalho, L. C., Sousa, M. A., Madeira, S. V., Sousa, P. J., \& Tano, T. (2007). Endothelium-dependent vasodilator effect of Euterpe oleracea Mart. (Açaí) extracts in mesenteric vascular bed of the rat. Vascular Pharmacology, 46, 97-104.

Rogez, H. (2000). In P. A. Belém (Ed.), Açaí: Preparo, composição e melhoramento da conservação ( $1^{\mathrm{a}}$ ed.). . : Universidade Federal do Pará - EDUFA.

Roininen, K., Lähteenmäki, L., \& Tuorila, H. (1999). Quantification of consumer attitudes to health and hedonic characteristics of foods. Appetite, 33, 71-88.

Roininen, K., Tuorila, H., Zandstra, E. H., de Graaf, C., Vehkalahti, K., Stubenitsky, K., et al. (2001). Differences in health and taste attitudes and reported behavior among Finnish, Dutch and British consumers: A cross-national validation of the Health and Taste Attitude Scales (HTAS). Appetite, 37, 33-45.

Rozin, P. (1990). Development in the food domain. Developmental Psychology, 26(4), $555-562$.

Sabbe, S., Verbeke, W., Deliza, R., Matta, V. M., \& van Damme, P. (2009a). Consumer liking of fruit juices with different açaí (Euterpe oleracea, Mart.) concentrations. Journal of Food Science, 74(5), S171-S176.

Sabbe, S., Verbeke, W., Deliza, R., Matta, V., \& Van Damme, P. (2009b). Effect of a health claim and personal characteristics on consumer acceptance of fruit juices with different concentrations of açaí (Euterpe oleracea Mart.). Appetite, 53, 84-92.

Schauss, A. S., Wu, X., Prior, R. L., Ou, B. O., Huang, D., Owens, J., et al. (2006). Antioxidant capacity and other bioactivities of the freeze-dried Amazonian palm berry, Euterpe oleraceae Mart. (Açaí). Journal of Agricultural and Food Chemistry, 54, 8604-8610.

Schauss, A. G., Wu, X., Prior, R. L., Ou, B., Patel, D., Huang, D., et al. (2006). Phytochemical and nutrient composition of the freeze-dried amazonian palm berry, Euterpe oleraceae Mart. (Açí). Journal of Agricultural and Food Chemistry, 54, 8598-8603.

Siegrist, M., Stampfli, N., \& Kastenholz, H. (2008). Consumers' willingness to buy functional foods. The influence of carrier, benefit and trust. Appetite, 51(526-5), 29.

Souza, M. O., Silva, M., Silva, M. E., Oliveira, R. P., \& Pedrosa, M. L. (2010). Diet supplementation with açaí (Euterpe oleracea Mart.) pulp improves biomarkers of oxidative stress and the serum lipid profile in rats. Nutrition, 26(7-8), 804-810.

Steptoe, A., Pollard, T., \& Wardle, J. (1995). Development of a measure of the motives underlying the selection of food: The food choice questionnaire. Appetite, 25, $267-284$

Steptoe, A., \& Wardle, J. (1992). Cognitive predictors of health behavior in contrasting regions of Europe. The British Journal of Clinical Psychology, 31, 485-502.

Sullivan, S. A., \& Birch, L. L. (1990). Pass the sugar, pass the salt: Experience dictates preference. Development Psychology, 26, 546-551.

Sveinsdóttir, K., Martinsdóttir, E., Green-Petersen, G., Hyldig, G., Schelvis, R., \& Delahunty, C. (2009). Sensory characteristics of different cod products related to consumer preferences and attitudes. Food Quality and Preference, 20, 120-132.

Teh, T., Dougherty, M. P., \& Camire, M. E. (2007). How do consumer attitudes influence acceptance of a novel wild blueberry-soy product? Journal of Food Science, 72, $516-521$. 
Tepper, B. J., Choi, Y. S., \& Nayaga, R. M. (1997). Understanding food choice in adult men: Influence of nutrition knowledge, food beliefs and dietary restraint. Food Quality and Preference, 8, 307-317.

Teratanavat, R., \& Hooker, N. H. (2006). Consumer valuations and preference heterogeneity for a novel functional food. Journal of Food Science, 71, S533-S541.

Tudoran, A., Olsen, S. O., \& Dopico, D. (2009). The effect of health benefits information on consumers health value, attitudes and intentions. Appetite, 52, 568-579.

Tuorila, H., \& Cardello, A. V. (2002). Consumer responses to an off-flavor in juice in the presence of specific health claims. Food Quality and Preference, 13, 561-569.

Tuorila, H., Meiselman, H. L., Bell, R., Cardello, A. V., \& Johnson, W. (1994). Role of sensory and cognitive information in the enhancement of certainty and liking for novel and familiar foods. Appetite, 23, 231-246.

Urala, N., \& Lähteenmäki, L. (2004). Attitudes behind consumers' willingness to use functional foods. Food Quality and Preference, 15, 793-803.

Urala, N., \& Lähteenmäki, L. (2007). Consumers' changing attitudes towards functional foods. Food Quality and Preference, 18, 1-12.

van Kleef, E., van Trijp, H. C. M., \& Luning, P. (2005). Functional foods: Health claim-food product compatibility and the impact of health claim framing on consumer evaluation. Appetite, 44, 299-308.

Verbeke, W. (2005). Consumer acceptance of functional foods: Socio-demographic, cognitive and attitudinal determinants. Food Quality and Preference, 16, 45-57.

Verbeke, W. (2006). Functional foods: Consumer willingness to compromise on taste for health? Food Quality and Preference, 17, 126-131.
Vidigal, M. C. T. R., Minin, V. P. R., Carvalho, N. B., Milagres, M. P., \& Goncalves, A. C. A. (in press). Effect of a health claim on consumer acceptance of exotic Brazilian fruit juices: açaí (Euterpe oleracea, Mart.), camu-camu (Myrciaria dubia), cajá (Spondias lutea L.) and umbu (Spondias tuberose Arruda). Food International Research.

Vigneau, E., Qannari, E. M., Punter, P. H., \& Knoops, S. (2001). Segmentation of a panel of consumers using clustering of variables around latent directions of preference. Food Quality and Preference, 12, 359-363.

Wang, S., Melnyk, J. P., Tsao, R., \& Marcone, M. F. (2011). How natural dietary antioxidants in fruits, vegetables and legumes promote vascular health. Food Research International, 44, 14-22.

Wardle, J., \& Steptoe, A. (1991). The European health and behavior survey: Rationale methods and initial results from the United Kingdom. Social Science E Medicine, 33 925-936.

West, G. E., Gendron, C., Larue, B., \& Lambert, R. (2002). Consumers' valuation of functional properties of foods: Results from a Canada-wide survey. Canadian Journal of Agricultural Economics, 50, 541-558.

WHO (2004). Food and Health in Europe: A new basis for action. WHO Regional Publications European Studies, 96, http://www.euro.who.int/_data/assets/ pdf_file/0005/74417/E82161.pdf last accessed in 11/30/2010.

Yuyama, L. K. O., Aguiar, J. P. L., Melo, T., Barros, S. E., Filho, D. F. S., Yuyama, K., et al. (2004) Açaí (Euterpe oleracea Mart.): Qual o seu potencial nutricional? XVII Congresso Brasileiro de Fruticultura. Florianópolis,Santa Catarina: Sociedade Brasileira de Fruticultura. 